\title{
THE AGRARIAN SECTOR OF ECONOMY: PROBLEMS OF SUSTAINABLE DEVELOPMENT IN THE CONTEXT OF GLOBAL ECONOMIC DYNAMICS SLOWDOWN, INCREASING THE UNCERTAINTY AND INSTITUTIONAL CONTRADICTION
}

\section{Sergiy Petrukha ${ }^{1}$ \\ Bohdan Stakhov ${ }^{2}$}

DOI: https://doi.org/10.30525/978-9934-588-38-9-32

\begin{abstract}
The results of investigation were represented; the methodological aspects of the sustainable development of the economic agricultural sector from the perspective of global regulation and coordination of the food problem overcoming, taking into account the world economic dynamics slowdown, the growth of uncertainty and institutional contradictions in the national, economic, political and social sphere were studied in the work. The object of the investigation is the problem of sustainable development of the agricultural sector of the economy, the investigation subject is the activity of mega-regulators represented by the UN and the FAO, aimed at the sustainable development of agriculture and the food market in the conditions of growing the national and regional economic, social and political risks, the achievement by the agricultural sector of the SDGs economy, in particular on liquidation of global hunger, and the aim of the investigation is regional dimensions of the UN and organizations of the "UN Family" policy in four vector adaptive model of sustainable development of the agricultural sector and food security ensuring: "availability - accessibility - usage - stability".

The multifaceted approach to the investigation of socio-economic problems of ensuring the sustainable development of the economic agricultural sector as a result of global regulation and coordination of this process by the UN and organizations of the "UN Family" has become the methodological base of this research, which allowed to formulate a number of scientific and methodological concepts, in particular.
\end{abstract}

${ }^{1}$ Candidate of Economic Sciences,

Associate Professor of the Department of Financial and Economic Security,

"KROK" University, Ukraine

${ }^{2}$ Postgraduate Student of the Faculty of Economics,

Taras Shevchenko National University of Kyiv, Ukraine 
The equivalency and interdependence of the "economic growth - social well-being - environmental sustainability" triad run like a golden thread through the SDGs, which by the means of fundamental link between people and the planet involve the economic agricultural sector into the sustainable food production and rural areas development, stimulating the achievement of all UN program goals for the period by 2030. Along with this, population growth, including the global food resource base depletion, questions the international community about the effective measures developing to overcome the crisis.

In this regard, it can be said that the FAO foundation has become a rather effective institutional option for solving the problem of sustainable development of the economic agricultural sector. The symbiosis of economic, social and political mechanisms has allowed not only to stop world hunger-bitten people growth, but also to formulate the ambitious goal of "Zero Hunger" ensuring the formation of a unitary mental-target space for the stakeholder activity, coordinated by the organization and aimed at its implementation. It made possible to reappraise the "Agricultural Outlook" prepared by the consolidated efforts of the OECD and FAO for the period 2017-2026 from the perspective of the SDGs and FAO policy impact on the invariance of the food market changes and changes in the group of key food consumers countries, also it made possible to predict the achievement of the relevant SDG targets for the period up to 2030 based on the given short and medium term outlooks for leveling a range of risks. This process will be facilitated by "FAO-diplomacy", as key tool for the agricultural production systems stimulation and specific locations as SDGs achievement, taking into account possible risks, as well as growth of uncertainty and institutional contradictions in the development of state regulatory institutions in developing countries in general and particularly in Ukraine.

\section{Introduction}

In the first quarter of the 21 st century, much attention is given to the consideration and search for solutions the global challenges that the world community faces. After the making up in 2015 about implementation the global goals, set at the Millennium Summit in 2000, the United Nations (UN) member states assumed new responsibilities until 2030, in particular, for settlement of a hunger problem and conservation of animal and plant genetic resources for food production and farming, for the agricultural sector stability. 
As noted in the United Nations Food and Agriculture Organization (FAO) regulatory and policy documents "food and agriculture are critical to achieving the Sustainable Development Goals by 2030 especially in ending hunger and malnutrition, transforming the food systems which unify people all over the world, the world's ecosystems sustentation, preserving and restoring natural resources, climate action and its consequences, development inclusive, evenhanded and peaceful societies" [56].

Considering the problem of sustainable economic agricultural sector development, it should be noted its integrated nature, that is determined by the close interconnection with the synchronized slowdown and unstable prospects of the global economy, which give rise to the economic operators' detrimental effect on the environmental conditions, social and human capital development. In this context there are some statements of Gita Gopinath and Qu Dongyu. The Chief Economist of the International Monetary Fund (IMF), Gita Gopinath, emphasizes "there is a synchronized slowdown in the global economy, and forecast of growth in 2019 was again reduced - to $3 \%$, the lowest level since the global financial crisis.

The growth is still dragged down by the growing trade barriers and increasing geopolitical tension between the USA and China, which in entirety will reduce $0,8 \%$ the global GDP to 2020 by low productiveness growth rate and population greying in advanced economies" [66]. FAO Head Qu Dongyu noticed "at the moment it is necessary to formulate the principles of an effective policy that will allow us to cope with the tasks that humanity faces in the framework of food security ensuring on a global scale" [37]. The statements of the IMF Chief Economist Gita Gopinath and FAO Head Qu Dongyu demonstrate the high level of world-spanning coordination in addressing the sustainability concerned the development of the agricultural sector, tension reduce in the geopolitical trade in the framework of synchronized slowdown and uncertain global economy dynamics recovery.

In defiance of continuing unprecedented economic growth over the past 150 years, a reduction in the number of poor people living on less than two USA dollars per day (at Purchasing Power Parity; PPP) has declined since 1981 from $42,1 \%$ to $9,9 \%$ in 2015 , herewith at the beginning of 2019 every ninth person in the world could not allow himself to eat a wholefood diet. As a result, the predictions of futurologists, including Keynes's legendary essay "Economic Opportunities for Our Grandchildren" [49], which sub- 
stantiates the possibility of a fifteen-hour work week and the early achievement of general prosperity, turned out to be erroneous. Actively developing inequality (both in the international arena and domestically) left a significant group of people - up to 820 million "overboard" the success achieved by the world [62], including those related to overcoming hidden hunger, gender inequality in agriculture, and a high level of dependence the farmers' activity from natural and climate conditions, access to world markets for agricultural raw materials and finished commodity.

Hunger, as a social disaster, has accompanied humanity at all stages of its evolution and nowadays it continues to be a global problem. But in modern conditions of scientific and technological progress and democratic transformations of the world order, there is a real opportunity to solve the global food problem jointly. That is why in recent years the synergy of the concepts of sustainable agricultural sector development and food security has come on the foreground of outlined problems' scientific research, the fundamental principles of mentioned concepts were formulated in the middle of the twentieth century. A huge number of scientific publications at planet-and-nation scale has been devoted to these problems, among the publications a special place was occupied by works of foreign economists (P. Barry, J. Boek, F. H. Cardoso, R. Desai, S. Devereux, B. Gardner, W. Hynes, A. Lewis, R. E. Lukas, S. Martin, R. Nurkse, R. Prebisch, L. Robison, P. M. Romer, W. Rostow, S. Scott, A. Sen) and of domestic economists (I. K. Bystriakov, Y. M. Gadzala, M. V. Gladiy, S. S. Hasanov, M. A. Khvesyk, O. V. Kovalova, M. M. Kropyvko, I. I. Lukinov, Yu. O. Lupenko, M. Y. Malika, V. Ya. Mesel-Veseliak, N. I. Patyka, S. V. Petrukha, P. T. Sabluk, O. M. Shpychak, O. G. Shpykuliak, L. D. Tulush, V. M. Zhuk).

Despite a rather high level of theoretical study the issues of sustainable economic agrarian sector development, neither at global nor at national scale it didn't get a chance to achieve the ambitious program goal of the Millennium Declaration (Millennium Development Goals; MDGs) - to halve the global hunger by 2015 . The poverty level in Ukraine remains persistently high (in $2015,23,8 \%$ of the population was below the relative poverty line [15]), while Ukrainians spend 44,5\% [2] of their income on food and non-alcoholic beverages, in developed countries this indicator ranges from $8 \%$ to $30 \%$ [4] (according to the UN standard of living interpretation, the country where the share of food costs in the total cost structure is $60 \%$ or 
more is considered extremely poor, 50-60\% - with a low standard of living, $40-50 \%$ - below average, $30-40 \%$ - average, $20-30 \%$ - above average and $20 \%$ and less - high [22]).

The counterintuitive situation for our country is, in accordance with the national report "Millennium Development Goals (Ukraine: 2000-2015)" [25], about declaring the accomplished achievement of task 1.A "Poverty Elimination by 2015 at criterion 5,05 USA dollars per day at PPP" to a level of less than $0,5 \%$, but actually at this criterion and the absolute poverty indicator "by the end of 2015 the growth is expected to reach 32\%" [25], this is an ascertaining the low level of state institutions regulatory ability in coordination and stimulating economic operators in national MDG priorities achievement.

From the point of view of the economic agrarian sector activity, rooting the discordant effect of global and national regulatory priorities (for example, in the Strategy for the Development of Agricultural Sector of Economy until 2020 [16] there aren't any passages to the MDGs or program goals of the FAO), their absence of pattern and high level of populist turbulence along with the growth of uncertainty and institutional contradictions engendered the inertia of its development orthodox path, which was low-oriented to methodological, methodical and almost formed requirement to the sustainability of its evolution. In addition, it should be noted that $[5-6 ; 13 ; 16 ; 54]$ :

firstly, as far as is known, Ukraine owns approximately $11 \%$ of the world's black humus earth storage (29 million ha), its share in the world's population is only $0,7 \%$, and despite the increase in self-sufficiency in certain food groups, the issues of import substitution by products with a high level of additional cost and search for new traditional products' markets outside the CIS countries are of particular relevance and require not only state interference, but the help of specialized institutions of the "UN Family" in particular FAO;

secondly, the increased state attention to the problems of sustainable development of the economic agricultural sector, apparent in the activating of state support to domestic agricultural commodity producers in the diverse forms and methods, promoted the growth of agricultural plant production. However, it is characterized by their modest effectiveness, and first of all, by the low level of budget funds usage with an emphasis on large corporate structures; 
thirdly, the existing mechanism of state regulation the sustainable development of the economic agricultural sector, factually reproduces the disparity in commodity-money relations in the sector, and does not sufficiently take into account the undertaken international obligations in the framework of the UN and FAO program goals;

fourthly, insufficiently developed mechanisms for opening the land market (data date 20 February 2020, the Supreme Council considered more than $25 \%$ of amendments to the bill № 2178-10 [27]) could negatively affect the food sovereignty of Ukraine and its role in ensuring the world food security, substantially distorting the structure of the agricultural sector of the economy, outlining the boundaries of the sustainability of its development for the next five to ten years.

Separately, it is worth mentioning that, unfortunately, the direct influence of the UN and FAO on changes in the agricultural sector of the economy as a whole, the configuration of the lines of sustainable development through the MDGs, the UN Sustainable Development Goals until 2030 (SDGs) not only did not find the proper reflection in the regulatory area (in fact, they found their parrying only 30 September 2019 (after a four-year implementation period) in The Edict of the President of Ukraine "On the Sustainable Development Goals of Ukraine for the period until 2030" [18]), but also in the national one (it is worth noting only a few works by O. G. Bilorus, P. T. Sabluk, M. V. Zubets, V. I. Vlasov, S. V. Petrukha and M. A. Khvesyk $[12 ; 14 ; 19-20])$ and in the russian speaking (N. S. Ivannikova, I. P. Lupashko-Stalskyi [8-9]) scientific literature there is lack of attention to these issues because of concentrating mainly on reference publications.

In this regard, it seems important to study the methodological aspects of the sustainable development of the agricultural sector from the perspective of global regulation and coordination of overcoming the food problem, taking into account the slowdown in the global economic dynamics, the growth of uncertainty and institutional contradictions in the national economic, political and social sphere, which also determines the novelty and relevance of the investigated topic.

The object of the investigation is the problem of sustainable development of the agricultural sector of the economy, the investigation subject is the activity of mega-regulators represented by the UN and the FAO, aimed at the sustainable development of agriculture and the food market in the 
conditions of growing the national and regional economic, social and political risks, the achievement by the agricultural sector of the SDGs economy, in particular on liquidation of global hunger, and the aim of the investigation is regional dimensions of the UN policy and organizations of the "UN Family" in four vector adaptive models of sustainable development of the agricultural sector and food security ensuring: "availability - accessibility - usage - stability".

To achieve this goal, it is necessary to solve the following tasks that determined the logic of the investigated material presentation:

1) to determine the role of the SDGs in programming the sustainability of global and regional (local) development of agriculture and agricultural-food chains of high added cost;

2) to investigate the background of FAO activities in the framework of the phenomenon of "Zero Hunger" in the conditions of changing economic and political component of the global food market;

3 ) to determine the impact of the triad "SDGs - global poverty - slowdown of global economic dynamics" on the transformation and development potential of the global food market;

4) to identify the features of FAO institutional decisions within the framework of regional priorities for achieving the sustainable development of agriculture and rural areas.

The multifaceted approach to the investigation of socio-economic problems of ensuring the sustainable development of the economic agricultural sector as a result of global regulation and coordination of this process by the UN and organizations of the "UN Family" has become the methodological basis of this research, which is due to the interdisciplinary nature of the issue under consideration. Thus, the institutional approach determined the basic theoretical parameters for studying the UN and FAO policy in the field of sustainable development of the agricultural sector of the economy and programmed transformation of the food market towards global food security support, and the historical approach made it possible to understand the evolution of global orientation and coordination on the need to ensure the sustainable development of agricultural production systems, their transparency and correlation with the conditions of a changing political, economic and social structure of the economic operators activity in the global, regional and local manufacturing market. 
There was methodologically important the exercising of system-oriented analysis, which allowed us to characterize the problem of sustainable development of the agricultural sector of the economy comprehensively in the conditions of modern global development, the core of which is the slowdown the world economic dynamics; the method of structural and functional analysis helped to determine the place and role of FAO and its related units in the structure of UN institutions; the comparative analysis method found to be useful in identifying the key food market tendencies in the context of administrative groups and regions, which allowed to investigate relevantly the features of the FAO program policy in the regional context.

To improve the perception of the research material, we display the list of generally accepted and specific abbreviations that were used in its narrative but have not been faced before: WFP - World Food Program; IFAD - International Fund for Agricultural Development; WHO - World Health Organization; OECD - Organization for Economic Co-operation and Development; NGOs - non-governmental organizations; EU - European Union.

\section{The United Nations global sustainable development goals in the context of programmable sustainability of dynamics of agricultural value-added chains}

In September 2015, within the framework of the 70th Session of the United Nations General Assembly, the UN Summit on Sustainable Development and Adoption of the post-2015 Development Agenda was held in New York, at which new development benchmarks were approved. By the final summit document "Transforming our World: The 2030 Agenda for Sustainable Development" [64], 17 SDGs and 169 targets were adopted.

Ukraine, like other UN member states, has joint a global process of support for sustainable development, in particular, in order to set the strategical framework of the national development for the period by 2030 based on the principle of "leaving no one behind", an inclusive process has been initiated to adapt the global goals. Among them, there are goals directly or indirectly associated with basic human needs and closely interconnected between themselves [26]:

Goal 1 - End poverty in all its forms everywhere;

Goal 2 - End hunger, achieve food security and improve nutrition and promote sustainable agriculture. 
For Ukraine, said goals are closely interconnected between themselves not only at the local but also at the global level, as, at the end of 2016, the UN World Food Program has recognized it as one of the key states involved in ensuring world food security. So, implementation of said goals in national sectoral high-level documents, in particular, the Strategy of Development of Agrarian Sector of Economy by 2030 [21], that is now widely discussed amid core branch civil society institutions, and point correction of the Strategy of Promotion of Attraction of Private Investments in Agriculture for the Period by 2023 [17] should implement a target of establishing, at national, regional and international levels, reliable strategical mechanisms, which would be based on development strategies taking into account the interests of lower income population strata, gender aspects, that, in aggregate, will promote accelerated investing in actions to eliminate poverty. Consistent implementation of listed strategic directions will make aid programs more accessible for the poor through food cheapening in world markets and improving its affordability for broad segments of the population of trade partner countries as well as - through international charity organizations - in other countries of the world. At the national level, this will promote implementing, by 2030, the targets [26]:

1) double the productivity of agriculture;

2) develop sustainable food production systems and introduce agriculture management practices enabling to enhance productivity and increase production volumes, promoting to preserve ecosystems, strengthen the capacity for adaptation to climate change, extreme weather events, droughts, flooding and other disasters and progressively improve land and soil quality;

3) increase investments, i.a., through enhanced international cooperation, in rural infrastructure, agricultural research and agro-propaganda, technology development and establishment of plant and animal gene banks in order to strengthen productive capacity of developing countries, in particular, least developed countries, in agriculture.

Consistent and efficient implementation of strategic directions will also promote achieving Goal 8 "Promote sustained, inclusive and sustainable economic growth, full and productive employment and decent work for all". We remind that, according to data [7], as of the end of 2018, nearly $3 \mathrm{M}$ persons worked in the agrarian sector of the national economy that makes $17.95 \%$ of the total number of the employed in Ukraine (16,360.9 $\mathrm{K}$ persons). In addi- 
tion, taking into account that it is the products of the food processing industry that are catering for almost the largest demand for transport and trade services, the multiplying effect for this sector of the economy is maximal. Accordingly, formation of the strategy for development of the agrarian sector of the economy of Ukraine by 2030 on the grounds of the UN Global Sustainable Development Goals for the same program period will not only promote increasing currency receipts to the country, but will also provide a surplus of the current account of the balance of payments (subject to continuous improvement of quality of these products, introduction of advanced technologies in their production, increase of labor productivity) and will also stimulate development of other sectors of the economy of Ukraine, and, thus, will become a carrier of sustainability and balance of economic growth, a foundation for overcoming the stagnation effect in the economy and levelling initiation of its crisis monetary and fiscal regulation. In addition, growth of the food processing industry will provide increasing external portfolio and capital investments in this sector of the economy and, thus, will promote implementation of the following targets for sustainable and inclusive development [26]:

1) increase economic productivity through diversification, technical modernization and innovative transformation of the sectors manufacturing high value-added products;

2) promote setting the goals, in economic development, aimed at intensifying production, creating new jobs and innovating activities and encouraging official recognition and development of micro-, small- and medium-sized enterprises, incl., access for them to financial resources;

3) progressively increase global efficiency of using resources in consumption and production systems and strive for economic growth with no harm to the environment according to the Decade Action Strategy for Transition to Use Rational Consumption and Production Patterns;

4) achieve full and, at the same time, productive employment and decent work for all women and men, incl. for young people and persons with disabilities, and equal pay for work of equal value.

Sustainable development of the agrarian sector of the national economy will promote formation of transport clusters, establishment of sustainable infrastructure incl. in rural construction, inclusive and sustainable infrastructure and innovations (Goal 9). In this context, a significant progress is seen in implementing the following targets [26]: 
1) develop quality, reliable, sustainable and affordable infrastructure, including regional and trans-border infrastructure;

2) promote inclusive and sustainable cluster industrialization, significantly increase, by 2030, the level of employment at cluster enterprises and its products' share of GDP in line with national circumstances;

3) through the high profitability level of products of the Ukrainian processing and food industry, facilitate access for cluster enterprises (incl. small- and medium-sized enterprises) to financial resources, incl. inexpensive credits, and enhance their integration into production and supply chains and markets (subject to compliance with phytosanitary norms);

3) modernize infrastructure and retrofit industry enterprises, making them sustainable through increased resource-use efficiency and broader application of clean and environmentally sound technologies and industrial processes;

4) establish a financial and institutional system, which will enable to develop scientific research and scientific and technical (experimental) inventions incl. through increasing the number of employees involved in research and inventions as well as state and private spending on them in the processing and food industry;

5) support development, research and innovations in food technologies, incl. through creating a political climate favorable, in particular, for industry diversification and value addition to products of the processing and food industry.

Active formation and implementation of institutional grounds for sustainability of functioning of the agrarian sector of the economy will promote achieving Goal 11 "Sustainable Cities and Communities", first of all, by stimulating development and implementation of local development strategies aimed at economic growth, creation of jobs and manufacture of local products. At the same time, implementing definite targets will promote achieving Goal 12 "Ensure sustainable consumption and production patterns", namely [26]:

1) halve, by 2030 , food losses in production and supply chains, incl. logistics and trade losses;

2) reduce waste generation volume and increase volumes of its recycling and reuse based on innovative technologies and productions;

3) recommend companies, in particular, large and transnational companies, to apply sustainable production practices and reflect information on rational use of resources in their reporting. 
Further implementation of best world practices of traceability and safety of products of the processing and food industry will unconditionally promote achieving, by Ukraine, Goal 14 "Conserve and sustainably use the oceans, seas and marine resources for sustainable development". To this end, it is necessary to implement the following targets [26]:

1) significantly reduce (by 2025) marine pollution, i.a., from land-based activities, including marine debris and nutrient pollution;

2) implement efficient regulation of marine bio resources harvesting.

Like marine ecosystems, sustainable development of the agrarian sector of the economy will also promote achieving Goal 15 "Protect and restore terrestrial ecosystems" through implementing the following targets [26]:

1) ensure conservation, restoration and sustainable use of terrestrial and inland freshwater ecosystems;

2) restore degraded lands and soils by using innovative technologies;

3) promote equitable sharing the benefits from the use of genetic resources and promote appropriate access to such resources on the terms agreed at the international level;

4) take actions to prevent poaching and trafficking of flora and fauna (incl., through expanding opportunities available to the local population to receive funds to support their life activities in an environmental-friendly manner), solve the problem of both demand and supply of illegal wildlife products.

One of the most important UN Global Sustainable Development Goals, which will be possible to be achieved through long-term development of export of products of the processing and food industry, is Goal 17 "Partnership for sustainable development", in particular, this will be promoted by implementing the following targets [26]:

1) mobilize additional financial resources based on stimulation of resident and nonresident investment activities;

2) extend cooperation in science, technology and innovations, their popularization and access to relevant achievements;

3) enhance knowledge sharing on mutually agreed terms, incl. through improved coordination between existing mechanisms, in particular, at the UN level as well as through a global technology transfer facilitation mechanism;

4) promote development, transfer, dissemination and mastering of environmentally sound technologies, first of all, for developing countries, on mutually agreed favorable terms, incl. on concessional and preferential 
terms. In this respect, Ukraine, through its sufficiently high technological level, is able to act not only as an advanced technology user but also as its supplier;

5) enhance international support for implementing effective and targeted capacity building of countries to promote implementation of national plans to achieve all goals of sustainable development;

6) enhance global macroeconomic stability incl. through policy coordination and ensuring its coherence;

7) form more coherent policy on support for sustainable development;

8) enhance the global partnership for sustainable development, complemented by multi-stakeholder partnerships that mobilize and share knowledge, experience, technology and financial resources to achieve sustainable development goals in all countries, in particular, in developing countries;

9) develop partnership relations between power and business to achieve the UN Global Sustainable Development Goals.

\section{3. "Zero Hunger" as a global vector of FAO activities in the context of new economic and political reality}

The UN is a central link in the global regulation system in the context of new economic and political reality. A lot of criticism of the UN managerial efficiency has been outspoken by the expert community in the recent years, however, there is no denying certain success, in particular, in such area as program activities of specialized organizations of the "UN Family".

It was articulated in the FAO, WFP and IFAD "The State of Food Security in the World" report [62], that at the time of completion of the period of the international monitoring of results achieved in the implementation of huger reduction targets (one of the Millennium Development Goals, for which the results of the fulfillment of obligations by the US member-states were summed up), a share of the underfed in the world has decreased from $23.3 \%$ to $12.9 \%$ over the last 25 years. Despite achieving rapid progress in Latin America, Central and Southeastern Asia, Oceania, the required progress results still failed to be achieved in many countries in Africa and on Caucasus. This is why, in opinion of former Director-General Graziano da Silva, [29], a strategic goal for FAO should be a target to eliminate such distress as hunger within the life-span of our generation and achieve the "Zero Hunger" SDG. This goal should be at the center of a new agenda of 
sustainable development. This idea was also outspoken by the IFAD President [34] with that spirit that creating the world without distress and hunger requires of the states of the world to rethink policies and concentrate on investing in rural areas, especially needed by developing countries. Liquidation of hunger ("Zero Hunger" program) is goal two on the SDG list. The problem of hunger cannot be solved through increasing food production only. Attention should be drawn to proper functioning of markets, growth of incomes of small farmers, equal-right access to technologies and land, growth of volume of investments in sustainable agriculture.

Actually, what is meant here is the most important social and political task - meeting the 1966 International Covenant on Civil and Political Rights [45], which secured a human right to quality and balanced nutrition. However, fulfilling some points of this covenant and realizing human rights to supply food in regions of Asia, Africa, the Caribbean Basin etc., is in question because of low incomes of the population.

For evaluating a situation of the states, it is needed to be guided by current standards on this matter. Understanding of the fact of population underand over-nutrition depends on existing standards set by medical indicators. Today, we can distinguish at once several evaluation methods, but one of the most popular is the standard of most western countries - "2,800-3,000 kcal per day and $90 \mathrm{~g}$ of protein, at least half of which is animal protein" [10]. An important detail in the WHO guidelines - "a healthy diet is determined not only by the quantity or quality but also by a variety, and the implementation of these tree parameters provides balanced nutrition" [41]. Currently, there is a number of circumstances preventing ensuring food security. Among them, there are some requiring special attention - for example, shortage of freshwater for the needs of the agrarian sector of the economy, satisfaction of population needs. In connection with the drying up of a number of rivers (for example, the Aral Sea Basin), the countries need to resort to mastering new methods of managing agriculture that often is a target difficult to be met. As of today, "we can also observe significant depletion of the World Ocean resources - in the 80s of the 20th century, some fish species were annihilated at $80-90 \%$, that, jeopardizes a chance to rebuild population [57]. We note that, traditionally, fish products are highly consumed in Japan that is part of national culture and a possibility of decreasing resource harvesting in the region is quite problematic. Another negative 
factor for food production is humanity activities - an adverse impact on the environment (on soil, air, water). All these reasons are a source of decline in productivity of agricultural resources that, naturally, results in reduction in quantitative and qualitative food production indicators. The existence of conflicts also adversely impacts the food security status. The FAO does not leave unattended this aspect and attempts not only trace and evaluate an adverse impact but also raise the question of the need for taking actions onto a higher level, to the UN Security Council [50].

In order to evaluate the development of the hunger problem, the Global Hunger Index [39], is used, which is calculated by several indicator groups. The advantage of this index at the current stage is in its comprehensiveness. Its value can be from 0 to 100, but actually there is no score higher than 60 - Figure 1 .

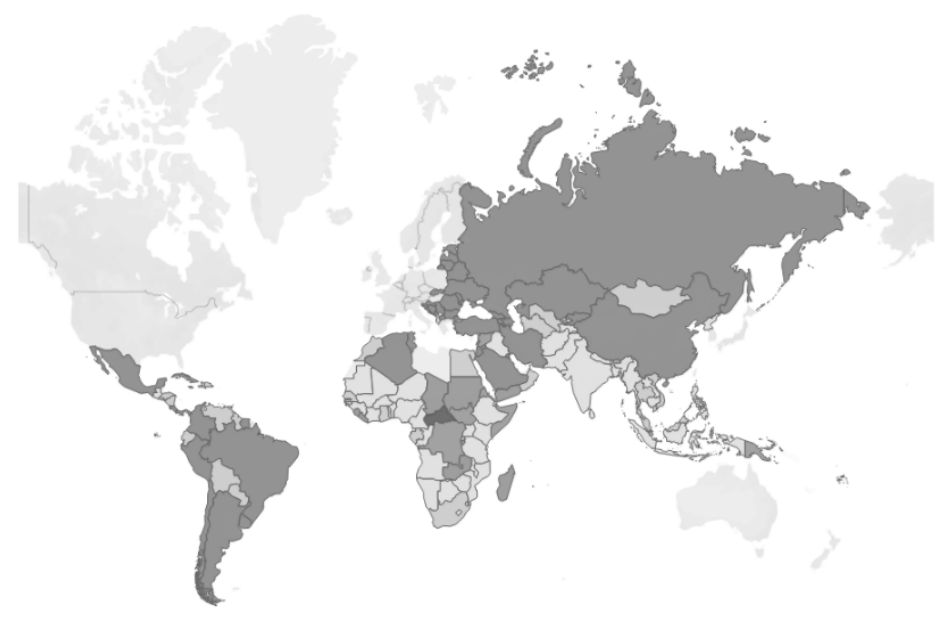

Figure 1. Global Hunger Index 2017 [39]

Indicators can be interpreted as follows: 1) the indicator up to 5 percent is deemed to be low; 2) from 5 to 15 - moderate; 3 ) the value from 15 to 25 shows the existence of significant problems; 4) from 25 to 35 informs of a dangerous situation; 5) when higher than this, the situation is recognized as extremely worrying.

Along with the hunger map, within FAO and WFP, the Integrated Food Security Phase Classification [47] is developed. This classification allows 
to evaluate a danger level of a crisis situation and set the required volume of humanitarian aid. In addition, it makes a considerable contribution to the preparation of the huger map and allows to pointedly evaluate the situation. So, the impact of the desert locust spread (in Kenia alone, large swarms up to $60 \mathrm{~km}$ long and $40 \mathrm{~km}$ wide less than within a month, have filled all northern provinces of the country and some central regions, inflicting serious damage to crops and cattle left without pastures [35]) on the risk of losing food security of the Horn of Africa is demonstrated on Figure 2.

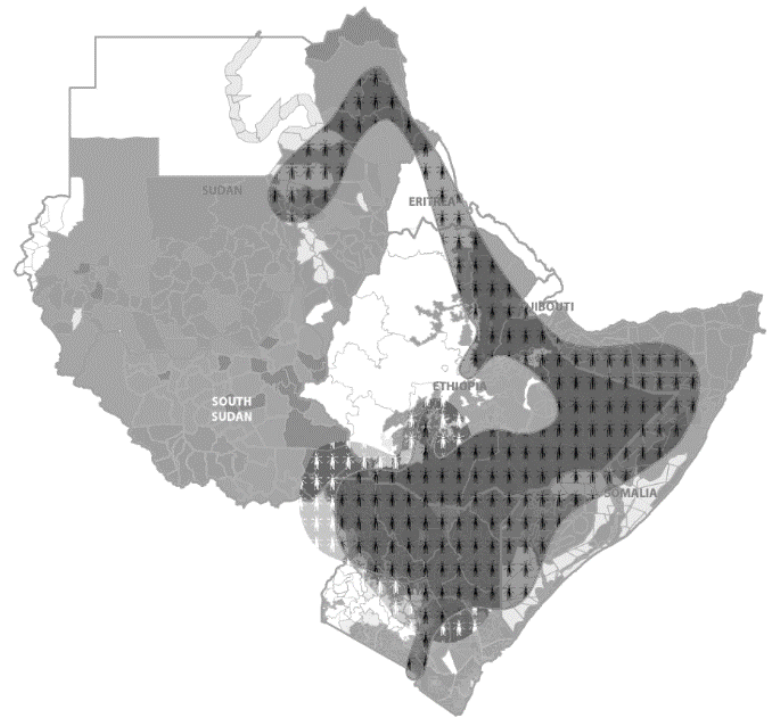

Figure 2. Acute Food Insecurity Phase Classification and Desert Locust Infestation [33]

Hunger maps are drawn up on the basis of data of two-year research by definite parameters. It is suggested to consider three map versions based on the FAO data for the last 10 years (2009 [60], 2014 [61], 2017 [63] and 2019 [62]), to evaluate changes in the "hunger geography". It needs to be noted that data improvement was made complicated in connection with objective circumstances, for example, with a military conflict within the state. 
As for the African continent:

1) in 2009, the highest food situation danger level was assigned to Zimbabwe, Zambia, Angola, Congo, Chad, CAR, Ethiopia, Tanzania, Namibia, Liberia. Moderate indicators have been achieved only in RSA as well in the countries of North and West Africa - Egypt, Tunisia, Algeria, Morocco, Mauritania, Mali. In all other countries of the continent, there have been significant problems with ensuring food security;

2) by 2014, the situation had slightly improved in Zimbabwe, Angola, Congo, Chad, Ethiopia, Tanzania, Liberia - they moved to a one status lower group. In other countries of the continent, no significant positive changes had taken place;

3 ) for some of these countries, the changes were temporary, because, negative changes had taken place in the African states by 2019, wherefrom the highest danger rating was assigned to several countries again, while for some of them - Chad, CAR, Congo, Uganda, Zambia, Zimbabwe, Madagascar, Liberia, for the first time for the period under review - in these countries, as of today, the situation is critical. The situation has slightly worsened for residents of Mali and Mauritania.

Having analyzed the status of the countries for the last decade, it is noticeable that the countries of North Africa compare favorably with the others, i.a., thanks to inflow of capital to the national economies from the tourism sector. Region-wide, the situation may be characterized as stably hard. Undoubtedly, it is significantly impacted by a number of military conflicts on the continent. So, according to the UN data [1], at the beginning of 2017, more than $20 \mathrm{M}$ people were at the edge of starvation in four countries of the world: Nigeria, Somali, South Sudan and Yemen because of violent conflict- and civil war-based crises. In such situations, the access to foodstuffs for people is restricted.

Evaluating the situation in North and South America, states of the Caribbean Basin, the following can be noted:

1) in 2009, on both continents, there was, mainly, a moderate-positive situation, except three countries - significant problems were seen in Bolivia and Nicaragua, and the status of Haiti is worth recognizing as critical - the Hunger Index indicator exceeded 50\%;

2) by 2014, all three danger situations had not changed, in some countries positive changes took place, among them are Paraguay, Peru, Ecuador. Columbia, Guiana, Guatemala, Honduras and Panama; 
3) by 2019, two significant changes had taken place - Venezuela and Salvador have moved to a more dangerous category with the indicator from 15 to $25 \%$. The rating of other states has not changed.

So, the situation on both continents may be recognized as stable - not many sharp changes took place in the status of the countries. None of the states, which situation is extremely hard during the latest 10 years, was able to achieve serious changes, while the situation in Venezuela has ever worsened in the course of the development of the political home crisis.

In Australia and Oceania, the situation has not undergone radical changes over the period under review, the indicators of Australia, New Zealand have remained low, in other states, except Timor-Leste - moderate. In the East Timor, the situation for the same period has improved - analyzed data are evidence of moving from the dangerous situation to the existence of significant problems.

Examining the data on Europe and Asia, the following conclusions can be arrived at:

1) in 2009, in the European part of the continent, low indicators prevailed, except Armenia, Albania and Georgia with moderate indicators. In the Asian part of the continent, the overall picture is significantly different. Extremely worrying was the situation in the DPRK, while in Yemen, Iraq, Pakistan, Afghanistan, Laos and Cambodia the situation was dangerous (indicator from 15 to $25 \%$ ), on the contrary, a low hunger indicator was fixed in Singapore, Malaysia, Kazakhstan and Turkmenistan only. In other states, the situation was moderate;

2 ) the status of a number of countries changed in 2014. The status of Iran and Albania improved, the situation in the DPRK remained the same critical, hunger indicators worsened in Yemen and Tajikistan;

3 ) by 2019 , a number of changes had taken place - the situation improved in the South Caucasus (Georgia, Armenia, Azerbaijan), the situation in Yemen and the DPRK remained critically high, the situation in Iraq and Afghanistan remained quite dangerous, significant hunger problems were fixed in Pakistan, Laos and Cambodia.

For many states of the region under study, the food shortage problem still remains current. Despite some successes (for example, situation improvement in the South Caucasus countries), main problems failed to get solved, and in some cases, even worsening was fixed. 
Generally, comparing indicators by all regions for the latest ten years, it can be noted that the world public has failed to achieve significant improvements. Local successes are accompanied by a stably hard food problem in a number of states of the world, which situation has not undergone any positive changes. Largely, it is explained by political and economic reasons, among which the most important are civil wars, ethnic conflicts, corruption of public officials and protracted ecological distresses (droughts, flooding etc.).

However, to achieve the "Zero Hunger" SDG, it is needed not only to eliminate hunger, but also ensure food security to prevent problematic situations in the future and create a platform for sustainable development. Currently, the problem of ensuring food security is aggravated by a number of factors. Price increase is among them - according to the FAO and OECD forecast up to 2021 [52], there will be no price decreasing, their level will be high enough, and this will take place against the background of global food production growth slowdown (largely, due to a failure to maintain previous growth rates). So, the Initiative on Soaring Food Prices [36] should be named as an important area of FAO activities, which - the prices - are of key significance for poor and developing states, for example, in Africa. It is carried out together with one of the main strategic partners of the FAO - the European Union.

Another not the least of the factors - climate change, which, by 2050, will critically impact on the sub-Sahara region. It is aggravated by poverty of the population (not only by the African population), which is named as one of the main obstacles for ensuring food security, in the Rome Declaration. Ibid, a plan for a possible solution to a food problem was presented, where the main tasks were specified [32]:

1) orientating the policy on elimination of poverty and inequality, universal access to food;

2) striving for readiness to unexpected crises and natural disasters;

3) achieving such environment in all spheres of life, which will allow to successfully and stably support food security;

4) popularizing agriculture as an industry for private capital infusions and citizen initiative.

Today, a number of FAO's basic regional programs can be noted (most of them are designed for the implementation in problematic regions). Among them are emergency response programs, aimed at providing aid for 
recovery after emergency situations and disasters, and applied just during such situations, as well as preventive action strategies. A bright example of such aid for crisis countries and regions is the Plan of Action to support agriculture and food security in Sudan [55]. Such plans are similar to each other and aimed at solving identical problems, inter alia [40]:

1) proving access to food resources in conflict zones;

2) training the locals to maintain the status of agricultural resources, not to allow their depletion:

2.1) adapting agricultural crops to climate change;

2.2) maintaining soil fertility;

2.3) managing water resources and controlling fishery;

3) eliminating an adverse human impact on the environment and production base resources;

4) assisting the state in defining and adopting legislative initiatives regulating the industry.

Programs of similar kind by the FAO and its affiliated structures really help both decrease possible damage and liquidate the consequences of crises and disasters, prevent potential threat to the food production resource base. As a consequence of this - carrying out the FAO activities in the main direction - to decline the hunger level and maintain food security. In this connection, such body needs to be mentioned as the Crop and Food Security Assessment Mission [48], which, within the framework of joint activities the WFP, helps assess food problems and render targeted aid that turns out to be needed in the context of liquidation of emergency situation consequences. Such programs have proven their efficiency for overcoming crisis consequences, but they are not sufficient enough at the time of the occurrence of the emergency situation itself. Jointly with the WFP, the Food Assistance for Assets program [38] is carried out, which promotes satisfying food needs and assists in working on improvement of the status of those state assets that make an impact on the food security implementation in the long term. Measures taken within this program in many countries of the world, every year help recover agricultural lands, green plantings and infrastructure of the agricultural sector as well as promote increasing in the skill level of the personnel employed in agriculture.

Joint FAO and WB programs [23], aimed at rendering aid and providing material resources are also permanent and significant projects of the 
organization designed not only for the liquidation of hunger itself, as a consequence, but also of its primary causes. Mutual activities of these two UN institutions are of long-term character, their joint work is not only of target character but is also aimed at improving the situation in general.

Attention should also be drawn to the Integrated Food Security Phase Classification [59] used by the FAO and WFP. This enables evaluating the crisis situation danger level and setting the required volume of humanitarian aid. In addition, it makes a significant contribution to the preparation of the huger map and enables evaluating the existing situation more pointedly.

An important point on the FAO programs list is the activities of the FAO Investment Center [46], with which assistance a large number of financial transactions has been made globally for the amount of more than $100 \mathrm{~B}$ US dollars. Its activities are investments in the agricultural sector as well as financial support for FAO specialized programs.

Having reviewed FAO programs for overcoming critical situations, it can be concluded that they have a real effect, their operation also promotes establishing the conditions to prevent worsening a food security problem.

It is interesting that, according to own Charter, the FAO has fair specified goals concerning the food and agriculture sphere only, but, after examination of the information on the above FAO programs, the conclusion can be made that, actually, its activities are of much wider character. It periodically operates in those spheres of activities, which seem as fair indirectly impacting a food supply problem. The FAO, in general, promotes improving the situation in developing countries both at the national level and directly interacting with the population.

However, within the framework of ensuring food security, there is not only a problem of hunger but also of obesity. According to the WHO data [51], the situation in the world is quite worrying. In 2016, nearly two B persons had excess weight, one third of them suffered from obesity - about $13 \%$ of the Earth population (in some countries more than $50 \%$ of the population). This indicator has increased more than threefold from 1975 to 2016 . For the recent three years, successes failed to be achieved globally, instead, the situation becomes even worse. According to the WHO data, by 2025, the number of people with excess weight will grow up to $46 \%$ globally and a share of the suffered from obesity will reach $17 \%$. 
In western experts' opinion, it can be said about a global obesity epidemic, that has become the most serious challenge for the healthcare system of the overwhelming majority of the countries of the world and has a very adverse impact on the economies of the states. It should be noted that the obesity problem is most often faced by residents of developing countries, which market, comparably not long ago, has become saturated with cheap food rich in calories and is not sufficiently regulated by the local legislation.

Persons suffering from obesity, in general, not only move less but also spend a lot of money on medical support and are limited in their labor activity choices. This made the WHO specialist conclude that obesity makes an impact not only on the health of the population but also on food security of the state. It is seen that one of the ways of overcoming this is an impact of the social factor, which would push the citizens to individual responsibility for their own nutrition. As already noted, before, a special impact on obesity is made by unhealthy nutrition, in particular, many people's passion for fast food products, consequently, promoting a healthy nutrition model by the state can be treated as a way of achieving food security.

So, it can be stated that the key role in solving a food problem in various regions of the world is played by the UN institutions and, foremost, by the FAO.

It is noted that the FAO development strategy provides a comprehensive approach to solving a food problem that means taking into account many factors impacting the food situation:

1) assistance in development of agriculture in various regions of the world;

2) development of scientifically grounded nutritional standards in both developing and developed countries;

3 ) constant monitoring of the status of availability of food to the population in various regions of the world; development of projects to solve food security problems at both national and regional levels.

The main FAO mechanism of solving said problems is various programs. Their analysis has shown their efficiency that is confirmed by the trend towards reduction in the number of the hungry as well as by growth in popularity of healthy nutrition and lifestyle among the population.

A bright example of the UN strategy for solving in practice the food problem is establishing the WFP, which activities are defined by the four main tasks [28]: 
1) helping people in emergency situations;

2) maintaining food security and liquidating consequences of emergency and crisis situations;

3) assisting in meeting population food needs;

4) decreasing in undernourishment indicator and promoting hunger liquidation.

In conclusion of reviewing the FAO program activities, the programs and projects can be divided into a number of groups:

1) depending on application regions;

2) target groups of needed states;

3) programs and projects by target tasks (for example, "Zero Hunger", "Think, Eat, Save").

Separately, a classification of FAO partners in solving the food problem can be given:

1) FAO substructures: Investment Center, WFP, etc.;

2) Specialized organizations of the "UN Family": IFAD, UNICEF, WHO, etc.;

3) donor countries: EU, USA, etc.;

4) non-state actors: INGOs, TNCs, charity foundations, etc.

Successes in the implementation of numerous FAO programs in various regions of the world show that just thanks to the purposeful and targeted aid policies in food security it succeeds to practically approximate the UN strategic goal to fall the hunger level in the world to zero marks. Although, the efficiency of the FAO programs often depends on objective factors - for example, civil wars and ethnic conflicts that makes the implementation of any level programs difficult or even impossible, however, in general, program activities of the FAO and related structures deserve a positive assessment.

\section{Impact of deeply coordinated regulation policy of sustainable development of agrarian sector of economy on structural and locational transformations of food market}

Dairy and dairy products. It is expected that consumption of fresh dairy products will increase in developing countries while developed countries will consume mainly processed products (Table 4.1). At the same time, world consumption of fresh dairy products and processed dairy products will grow during the next decade by $2.1 \%$ and $1.7 \%$ a year, respectively. 
In 2026, major consumers of dairy products will be developing countries, especially, countries in Asia (50\%), Africa (16\%) and Middle East (13\%).

Table 4.1

World Dairy Import Dynamics Projections

\begin{tabular}{|c|c|c|c|c|c|c|c|c|}
\hline \multirow{2}{*}{$\begin{array}{c}\text { Food group } \\
\text { name }\end{array}$} & \multicolumn{6}{|c|}{ Studied and outlook periods, Kt. } & \multicolumn{2}{c|}{ Variations 2016 by } \\
\cline { 2 - 9 } & $\mathbf{2 0 1 6}$ & $\mathbf{2 0 1 8}$ & $\mathbf{2 0 2 0}$ & $\mathbf{2 0 2 2}$ & $\mathbf{2 0 2 4}$ & $\mathbf{2 0 2 6}$ & Absolute & Relative,\% \\
\hline $\begin{array}{c}\text { Fresh dairy } \\
\text { products }\end{array}$ & 18 & 21 & 15 & 13 & 14 & 16 & -2 & 88.88 \\
\hline Cream butter & 873 & 905 & 968 & 1017 & 1076 & 1123 & 249 & 128.64 \\
\hline Hard cheeses & 2311 & 2428 & 2520 & 2607 & 2693 & 2792 & 481 & 120.81 \\
\hline $\begin{array}{c}\text { Skim milk } \\
\text { powder }\end{array}$ & 2164 & 2311 & 2376 & 2460 & 2555 & 2648 & 484 & 122.36 \\
\hline $\begin{array}{c}\text { Whole milk } \\
\text { powder }\end{array}$ & 2520 & 2558 & 2607 & 2689 & 2766 & 2857 & 337 & 113.37 \\
\hline Whey powder & 6350 & 6504 & 6913 & 7272 & 7742 & 8236 & 1886 & 129.70 \\
\hline
\end{tabular}

Source: author's source generalization [6; 12; 52-53]

In general, cheese import in developing countries will grow faster $(2 \%$ annually) than in developed countries (1.6\% annually). It is projected that the Russian Federation, Japan, China, USA and Mexico will become the top five cheese importers in 2026. Cheese and butter import by China will increase annually by $4.3 \%$ and $3.1 \%$, respectively. By 2026 , the share of world import will make $10 \%$ for butter and $7 \%$ for cheese and the Middle East and North Africa will have 19\% of world cheese import (Table 4.2).

Main butter importers are the Russian Federation, Egypt, China and Saudi Arabia that reflects growing in domestic consumption (Table 4.3). The Middle East and North Africa will cover 35\% of world butter import. Egypt will confirm its position as the major butter importer, with the share of $11 \%$ of world butter import by 2026 .

In developed countries, a recovered butter and dairy fat consumption enthusiasm is observed, versus consumption of vegetable oil-based substitutes. As the result of it, these products are increasingly used in bakery products and confectionary industry.

Developing countries will import $97 \%$ of world whole milk powder import (Table 4.4). It is projected that Asia will increase its import share 
Table 4.2

World Cheese Import Dynamics Projections by Region

\begin{tabular}{|c|c|c|c|c|c|c|}
\hline \multirow{2}{*}{ Region name } & \multicolumn{6}{|c|}{ Studied and outlook periods, Kt } \\
\cline { 2 - 7 } & $\mathbf{2 0 1 6}$ & $\mathbf{2 0 1 8}$ & $\mathbf{2 0 2 0}$ & $\mathbf{2 0 2 2}$ & $\mathbf{2 0 2 4}$ & $\mathbf{2 0 2 6}$ \\
\hline World & 2311 & 2428 & 2520 & 2607 & 2693 & 2792 \\
\hline Developed countries & 1049 & 1111 & 1150 & 1188 & 1218 & 1251 \\
North America & 229 & 220 & 222 & 226 & 227 & 228 \\
Europe & 406 & 467 & 498 & 529 & 556 & 585 \\
Oceania & 111 & 116 & 119 & 122 & 124 & 125 \\
Other developed countries & 304 & 308 & 311 & 312 & 312 & 313 \\
\hline Developing countries & 1262 & 1318 & 1369 & 1419 & 1475 & 1541 \\
Africa & 140 & 152 & 170 & 190 & 213 & 238 \\
Latin America and Caribbean & 328 & 349 & 358 & 357 & 354 & 355 \\
Asia & 794 & 817 & 841 & 872 & 908 & 949 \\
\hline
\end{tabular}

Source: author's source generalization [6; 12; 52-53]

Table 4.3

World Butter Import Dynamics Projections by Region

\begin{tabular}{|c|c|c|c|c|c|c|}
\hline \multirow{2}{*}{ Region name } & \multicolumn{6}{|c|}{ Studied and outlook periods, Kt } \\
\cline { 2 - 7 } & $\mathbf{2 0 1 6}$ & $\mathbf{2 0 1 8}$ & $\mathbf{2 0 2 0}$ & $\mathbf{2 0 2 2}$ & $\mathbf{2 0 2 4}$ & $\mathbf{2 0 2 6}$ \\
\hline World & 873 & 905 & 968 & 1017 & 1076 & 1123 \\
\hline Developed countries & 238 & 242 & 254 & 260 & 270 & 280 \\
North America & 49 & 34 & 30 & 26 & 22 & 22 \\
Europe & 114 & 133 & 147 & 156 & 167 & 176 \\
Oceania & 32 & 33 & 34 & 35 & 36 & 37 \\
Other developed countries & 44 & 42 & 43 & 44 & 45 & 46 \\
\hline Developing countries & 635 & 663 & 714 & 757 & 805 & 842 \\
Africa & 113 & 123 & 147 & 171 & 195 & 218 \\
Latin America and Caribbean & 70 & 66 & 66 & 67 & 68 & 68 \\
Asia & 452 & 473 & 500 & 519 & 542 & 556 \\
\hline
\end{tabular}

Source: author's source generalization [6; 12; 52-53]

from $59 \%$ to $62 \%$ by 2026 . China is the major importer and will import $22 \%$ of world milk powder trade by 2026. In 2014, China decreased in whole milk powder import, it is expected that it will recover but slowly enough (4.1\% annually). China will remain the world's major skim milk powder importer, with 5,3\% of annual import growth.

According to projections, import growth rates in other major importing countries - Egypt, Mexico, Algeria, Indonesia, Malaysia, Philippines and Viet- 
nam - will slow down during the projected period as compared to the last decade due to higher base levels as well as due to a limited increase in demand subject to predominance of fresh dairy product consumption (Table 4.5).

Table 4.4

World Skim Milk Powder Import Dynamics by Region

\begin{tabular}{|c|c|c|c|c|c|c|}
\hline \multirow{2}{*}{ Region name } & \multicolumn{7}{|c|}{ Studied and outlook periods, Kt } \\
\cline { 2 - 7 } & $\mathbf{2 0 1 6}$ & $\mathbf{2 0 1 8}$ & $\mathbf{2 0 2 0}$ & $\mathbf{2 0 2 2}$ & $\mathbf{2 0 2 4}$ & $\mathbf{2 0 2 6}$ \\
\hline World & 2164 & 2311 & 2376 & 2460 & 2555 & 2648 \\
\hline Developed countries & 284 & 291 & 284 & 283 & 282 & 280 \\
North America & 3 & 3 & 3 & 3 & 2 & 2 \\
Europe & 177 & 186 & 187 & 190 & 194 & 198 \\
Oceania & 11 & 11 & 11 & 11 & 11 & 11 \\
Other developed countries & 93 & 90 & 83 & 79 & 74 & 69 \\
\hline Developing countries & 1881 & 2020 & 2092 & 2177 & 2273 & 2368 \\
Africa & 347 & 357 & 375 & 392 & 418 & 438 \\
Latin America and Caribbean & 401 & 412 & 415 & 420 & 428 & 438 \\
Asia & 1133 & 1251 & 1303 & 1364 & 1428 & 1491 \\
\hline
\end{tabular}

Source: author's source generalization [6; 12; 52-53]

Table 4.5

World Whole Milk Powder Import Dynamics Projections by Region

\begin{tabular}{|c|c|c|c|c|c|c|}
\hline \multirow{2}{*}{ Region name } & \multicolumn{6}{|c|}{ Studied and outlook periods, Kt } \\
\cline { 2 - 7 } & $\mathbf{2 0 1 6}$ & $\mathbf{2 0 1 8}$ & $\mathbf{2 0 2 0}$ & $\mathbf{2 0 2 2}$ & $\mathbf{2 0 2 4}$ & $\mathbf{2 0 2 6}$ \\
\hline World & 2520 & 2558 & 2607 & 2689 & 2766 & 2857 \\
\hline Developed countries & 104 & 99 & 96 & 93 & 91 & 88 \\
North America & 12 & 11 & 11 & 11 & 11 & 11 \\
Europe & 58 & 54 & 51 & 49 & 46 & 44 \\
Oceania & 24 & 23 & 23 & 23 & 23 & 22 \\
Other developed countries & 10 & 10 & 10 & 10 & 10 & 11 \\
\hline Developing countries & 2416 & 2459 & 2512 & 2596 & 2675 & 2769 \\
Africa & 504 & 521 & 548 & 577 & 608 & 639 \\
Latin America and Caribbean & 481 & 452 & 427 & 418 & 399 & 395 \\
Asia & 1431 & 1486 & 1537 & 1601 & 1669 & 1735 \\
\hline
\end{tabular}

Source: author's source generalization [6; 12; 52-53]

Sugar. Sugar cane cultivated, mainly, in developing countries (Africa, Asia and South America), as before, will remain the major crop for sugar production. It is expected that the share of sugar made of sugar beet will slightly decrease from $14 \%$ in $2014-2016$ to $12.9 \%$ in 2026 (Table 4.6). 
Table 4.6

World Sugar Import Dynamics Projections

\begin{tabular}{|c|c|c|c|c|c|c|c|c|}
\hline $\begin{array}{c}\text { Food } \\
\text { group } \\
\text { name }\end{array}$ & \multicolumn{5}{|c|}{ Studied and outlook periods, Kt } & \multicolumn{2}{c|}{ Variation 2016 by 2026 } \\
\cline { 2 - 9 } & $\mathbf{2 0 1 6}$ & $\mathbf{2 0 1 8}$ & $\mathbf{2 0 2 0}$ & $\mathbf{2 0 2 2}$ & $\mathbf{2 0 2 4}$ & $\mathbf{2 0 2 6}$ & Absolute & Relative, \% \\
\hline Syrup & 4857 & 5369 & 5308 & 5253 & 5274 & 5390 & 532 & 110.97 \\
\hline Sugar & 51192 & 55355 & 57435 & 58832 & 61571 & 64004 & 12811 & 125.03 \\
Brown & 33151 & 36033 & 37282 & 38044 & 39803 & 40977 & 7826 & 123.60 \\
White & 18040 & 19323 & 20153 & 20788 & 21769 & 23027 & 4987 & 127.64 \\
\hline
\end{tabular}

Source: author's source generalization [6; 12; 52-53]

Import will remain diversified as more countries start importing, mainly, through the demand from Africa and Asia. Under projections (Table 4.7), the largest sugar import growth will be observed in Asia, Pacific region as well as in Africa. In the base period, China and Indonesia are the leading importers followed by the European Union. However, it is expected that in ten years, Indonesia and China will become the leading sugar importers, with the USA (with 5.9 M t, 5.9 Mt and 3.6 Mt, respectively).

Table 4.7

World Sugar Import Dynamics by Region

\begin{tabular}{|c|c|c|c|c|c|c|}
\hline \multirow{2}{*}{ Region name } & \multicolumn{6}{|c|}{ Studied and outlook periods, Kt } \\
\cline { 2 - 7 } & $\mathbf{2 0 1 6}$ & $\mathbf{2 0 1 8}$ & $\mathbf{2 0 2 0}$ & $\mathbf{2 0 2 2}$ & $\mathbf{2 0 2 4}$ & $\mathbf{2 0 2 6}$ \\
\hline World & 51192 & 55355 & 57435 & 58832 & 61571 & 64004 \\
\hline Developed countries & 12830 & 11879 & 12295 & 12475 & 12994 & 13131 \\
North America & 3560 & 3751 & 4054 & 4279 & 4548 & 4766 \\
Europe & 4673 & 3432 & 3579 & 3469 & 3652 & 3508 \\
Oceania & 361 & 367 & 369 & 375 & 377 & 381 \\
Other developed countries & 4236 & 4330 & 4294 & 4351 & 4417 & 4476 \\
\hline Developing countries & 38362 & 43476 & 45140 & 46357 & 48577 & 50873 \\
Africa & 11401 & 12573 & 13552 & 14083 & 15076 & 16175 \\
Latin America and Caribbean & 2097 & 1982 & 1984 & 1992 & 1966 & 1935 \\
Asia & 24864 & 28921 & 29605 & 30283 & 31535 & 32763 \\
\hline
\end{tabular}

Source: author's source generalization [6; 12; 52-53]

Meat. Weak growth is projected in import of meat of all types during first years of the projected period, mainly, due to import decrease from the largest consumers - China and Russia (Table 4.8). However, in the second half of the projected period import will start growing through increasing 
purchase volumes in developing countries. Highest growing in import of all kinds will be observed in Philippines and Vietnam as well as in Sub-Saharan African countries.

Table 4.8

World Major Type Meat Import Dynamics Projections

\begin{tabular}{|c|c|c|c|c|c|c|c|c|}
\hline \multirow{2}{*}{$\begin{array}{c}\text { Food group } \\
\text { name }\end{array}$} & \multicolumn{6}{|c|}{ Studied and outlook periods, Kt } & \multicolumn{2}{c|}{$\begin{array}{c}\text { Variation } \\
\mathbf{2 0 1 6} \text { by 2026 }\end{array}$} \\
\cline { 2 - 9 } & $\mathbf{2 0 1 6}$ & $\mathbf{2 0 1 8}$ & $\mathbf{2 0 2 0}$ & $\mathbf{2 0 2 2}$ & $\mathbf{2 0 2 4}$ & $\mathbf{2 0 2 6}$ & Absolute & Relative, \% \\
\hline Beef and veal & 10161 & 10788 & 11101 & 11465 & 11799 & 12131 & 1970 & 119.39 \\
\hline Pig meat & 8283 & 7703 & 7660 & 7794 & 7908 & 8121 & -162 & 98.04 \\
\hline Poultry & 11819 & 12506 & 12904 & 13385 & 13830 & 14226 & 2407 & 120.36 \\
\hline Sheep meat & 1326 & 1296 & 1338 & 1377 & 1416 & 1457 & 132 & 109.88 \\
\hline
\end{tabular}

Source: author's source generalization [6; 12; 52-53]

In the next ten years, the demand for meet will be weaker, mainly, through decreasing in pig meat import from China. It is partly compensated by enhancing beef meet import from Sub-Saharan African countries and Asian-Pacific region. During this period, meat production in China will be insufficient to meet the domestic demand that will require sizeable import. Further, a significant share of additional import will be fixed in Vietnam by all meat types that is backed by favorable economic growth. Africa is another rapidly growing region, although many countries start from the law base.

Import volume growth will take place through increasing purchase of poultry, major part of which will be imported by developing countries.

Additional growth in beef and veal meat import will take place, predominantly, also in developing countries, mainly, in Asian countries (Table 4.10).

While beef and veal meat trade growth will take place in developing countries, pork import increase will take place in developed countries (Table 4.11).

Cereals. Currently, supplies of major cereals in global markets continue to exceed demand. This contributes to building up inventories that, in turn, continues to put under negative pressure international market prices remaining significantly lower as compared to the previous years. Global cereal and grain consumption will likely increase by 2026 on average by $13 \%$ versus the base period up to $2,863 \mathrm{Mt}$. 
Table 4.9

World Poultry Import Dynamics Projections by Region

\begin{tabular}{|c|c|c|c|c|c|c|}
\hline \multirow{2}{*}{ Region name } & \multicolumn{7}{|c|}{ Studied and outlook periods, Kt } \\
\cline { 2 - 7 } & $\mathbf{2 0 1 6}$ & $\mathbf{2 0 1 8}$ & $\mathbf{2 0 2 0}$ & $\mathbf{2 0 2 2}$ & $\mathbf{2 0 2 4}$ & $\mathbf{2 0 2 6}$ \\
\hline World & 11819 & 12506 & 12904 & 13385 & 13830 & 14226 \\
\hline Developed countries & 3167 & 3330 & 3313 & 3290 & 3269 & 3231 \\
North America & 349 & 352 & 357 & 362 & 370 & 373 \\
Europe & 1409 & 1527 & 1497 & 1460 & 1417 & 1365 \\
Other developed countries & 1409 & 1452 & 1458 & 1468 & 1482 & 1494 \\
\hline Developing countries & 8652 & 9176 & 9591 & 10095 & 10561 & 10994 \\
Africa & 1164 & 1280 & 1398 & 1511 & 1608 & 1722 \\
Latin America and Caribbean & 1823 & 1823 & 1799 & 1855 & 1873 & 1851 \\
Asia & 5665 & 6073 & 6394 & 6729 & 7080 & 7421 \\
\hline
\end{tabular}

Source: author's source generalization [6; 12; 52-53]

Table 4.10

World Beef and Veal Meat Import Dynamics Projections by Region

\begin{tabular}{|c|c|c|c|c|c|c|}
\hline \multirow{2}{*}{ Region name } & \multicolumn{5}{|c|}{ Studied and outlook periods, Kt } \\
\cline { 2 - 7 } & $\mathbf{2 0 1 6}$ & $\mathbf{2 0 1 8}$ & $\mathbf{2 0 2 0}$ & $\mathbf{2 0 2 2}$ & $\mathbf{2 0 2 4}$ & $\mathbf{2 0 2 6}$ \\
\hline World & 10161 & 10788 & 11101 & 11465 & 11799 & 12131 \\
\hline Developed countries & 4013 & 4179 & 4276 & 4367 & 4450 & 4517 \\
North America & 1999 & 1994 & 2073 & 2099 & 2137 & 2165 \\
Europe & 923 & 1022 & 1026 & 1045 & 1055 & 1080 \\
Oceania & 24 & 24 & 24 & 24 & 24 & 24 \\
Other developed countries & 1067 & 1140 & 1153 & 1199 & 1234 & 1248 \\
\hline Developing countries & 6148 & 6609 & 6826 & 7098 & 7349 & 7614 \\
Africa & 902 & 1067 & 1126 & 1200 & 1265 & 1341 \\
Latin America and Caribbean & 907 & 966 & 990 & 1025 & 1060 & 1086 \\
Asia & 4339 & 4575 & 4710 & 4873 & 5023 & 5187 \\
\hline
\end{tabular}

Source: author's source generalization [6; 12; 52-53].

Global wheat consumption growth is expected by $11 \%$ in the period by 2026 (Table 4.13). It is projected that using wheat for feed will increase in China, Pakistan, Vietnam. Shares of the top five wheat importers (Egypt, Indonesia, Algeria, Brazil, Japan) will likely remain stably high.

Further, intensification is predicted for global maize consumption, namely, maize consumption growth per capita is expected, foremost, in African countries - on average by $3 \%$ a year. Further, Vietnam has preconditions to replace Egypt in the fifth place among the largest maize importers (Table 4.14). 
Table 4.11

World Pork Import Dynamics Projections by Region

\begin{tabular}{|c|c|c|c|c|c|c|}
\hline \multirow{2}{*}{ Region name } & \multicolumn{6}{|c|}{ Studied and outlook periods, Kt } \\
\cline { 2 - 7 } & $\mathbf{2 0 1 6}$ & $\mathbf{2 0 1 8}$ & $\mathbf{2 0 2 0}$ & $\mathbf{2 0 2 2}$ & $\mathbf{2 0 2 4}$ & $\mathbf{2 0 2 6}$ \\
\hline World & 8283 & 7703 & 7660 & 7794 & 7908 & 8121 \\
\hline Developed countries & 3192 & 3165 & 3229 & 3272 & 3290 & 3340 \\
North America & 862 & 833 & 899 & 934 & 943 & 983 \\
Europe & 666 & 651 & 652 & 655 & 657 & 642 \\
Oceania & 362 & 374 & 384 & 393 & 403 & 412 \\
Other developed countries & 1302 & 1307 & 1293 & 1289 & 1288 & 1304 \\
\hline Developing countries & 5091 & 4538 & 4431 & 4522 & 4618 & 4781 \\
Africa & 248 & 276 & 288 & 310 & 334 & 369 \\
Latin America and Caribbean & 1171 & 1221 & 1230 & 1234 & 1278 & 1305 \\
Asia & 3672 & 3041 & 2913 & 2978 & 3006 & 3106 \\
\hline
\end{tabular}

Source: author's source generalization [6; 12; 52-53]

Table 4.12

World Cereal Import Dynamics Projections

\begin{tabular}{|c|c|c|c|c|c|c|c|c|}
\hline \multirow{2}{*}{$\begin{array}{c}\text { Food } \\
\text { group } \\
\text { name }\end{array}$} & \multicolumn{5}{|c|}{ Studied and outlook periods, Kt } & \multicolumn{2}{|c|}{$\begin{array}{c}\text { Variation 2016 by } \\
\mathbf{2 0 2 6}\end{array}$} \\
\cline { 2 - 9 } & $\mathbf{2 0 1 6}$ & $\mathbf{2 0 1 8}$ & $\mathbf{2 0 2 0}$ & $\mathbf{2 0 2 2}$ & $\mathbf{2 0 2 4}$ & $\mathbf{2 0 2 6}$ & Absolute & $\begin{array}{c}\text { Relative, } \\
\text { \% }\end{array}$ \\
\hline Wheat & 168088 & 176045 & 171499 & 180267 & 184507 & 188709 & 20621 & 112,27 \\
\hline Maize & 139297 & 137256 & 139406 & 144416 & 149015 & 153315 & 14018 & 110,063 \\
\hline $\begin{array}{c}\text { Other } \\
\text { cereals }\end{array}$ & 37926 & 38880 & 40876 & 42653 & 44436 & 46119 & 8193 & 121,60 \\
\hline Rice & 42293 & 43311 & 45173 & 47018 & 48864 & 50768 & 8475 & 120,04 \\
\hline
\end{tabular}

Source: author's source generalization [6; 12; 52-53]

The third largest grain crop - rice - will also demonstrate positive dynamics (Table 4.15). It is expected that rice consumption will grow from $494 \mathrm{Mt}$ in the base period to $560 \mathrm{Mt}$ in 2026 . Highest growing will be observed in the largest regions of Asia - up to $80 \%$ of total growth, especially, in the countries of the Middle East as well as of Africa, Latin America and the Caribbean. Further, rice consumption will also increase in Europe. However, its largest importers will remain China, Nigeria, Cote d'Ivoire, Philippines and Saudi Arabia. 
Table 4.13

World Wheat Import Dynamics Projections by Region

\begin{tabular}{|c|c|c|c|c|c|c|}
\hline \multirow{2}{*}{ Region name } & \multicolumn{5}{|c|}{ Studied and outlook periods, Kt } \\
\cline { 2 - 7 } & $\mathbf{2 0 1 6}$ & $\mathbf{2 0 1 8}$ & $\mathbf{2 0 2 0}$ & $\mathbf{2 0 2 2}$ & $\mathbf{2 0 2 4}$ & $\mathbf{2 0 2 6}$ \\
\hline World & 168088 & 171499 & 176045 & 180267 & 184507 & 188709 \\
\hline Developed countries & 28411 & 27393 & 27486 & 27694 & 27924 & 28108 \\
North America & 3502 & 3516 & 3466 & 3763 & 4038 & 4300 \\
Europe & 8838 & 8200 & 8096 & 7913 & 7827 & 7784 \\
Oceania & 489 & 504 & 515 & 539 & 557 & 579 \\
Other developed countries & 15583 & 15173 & 15409 & 15480 & 15502 & 15446 \\
\hline Developing countries & 139676 & 144105 & 148558 & 152573 & 156584 & 160601 \\
Africa & 47154 & 48975 & 51230 & 53319 & 55421 & 57675 \\
Latin America and Caribbean & 21560 & 21774 & 22220 & 22633 & 23035 & 23379 \\
Asia & 70963 & 73357 & 75108 & 76620 & 78127 & 79546 \\
\hline
\end{tabular}

Source: author's source generalization [6; 12; 52-53]

Table 4.14

World Maize Import Dynamics Projections by Region

\begin{tabular}{|c|c|c|c|c|c|c|}
\hline \multirow{2}{*}{ Region name } & \multicolumn{5}{|c|}{ Studied and outlook periods, Kt } \\
\cline { 2 - 7 } & $\mathbf{2 0 1 6}$ & $\mathbf{2 0 1 8}$ & $\mathbf{2 0 2 0}$ & $\mathbf{2 0 2 2}$ & $\mathbf{2 0 2 4}$ & $\mathbf{2 0 2 6}$ \\
\hline World & 139297 & 137256 & 139406 & 144416 & 149015 & 153315 \\
\hline Developed countries & 37325 & 34942 & 33733 & 34660 & 34694 & 35043 \\
North America & 2397 & 2941 & 2871 & 2878 & 2837 & 2834 \\
Europe & 14832 & 14183 & 13086 & 13935 & 13999 & 14334 \\
Oceania & 148 & 125 & 126 & 132 & 134 & 138 \\
Other developed countries & 19948 & 17693 & 17650 & 17715 & 17723 & 17737 \\
\hline Developing countries & 101972 & 102314 & 105674 & 109756 & 114321 & 118272 \\
Africa & 22009 & 22215 & 22775 & 23715 & 24742 & 25939 \\
Latin America and Caribbean & 32126 & 31184 & 32406 & 32893 & 33416 & 33947 \\
Asia & 47837 & 48915 & 50493 & 53148 & 56164 & 58386 \\
\hline
\end{tabular}

Source: author's source generalization [6; 12; 52-53]

Oilseeds and products of their processing. In 2016, world production of oilseeds and, respectively, products of their processing has been increased first over the last few years (Table 4.16). Although, vegetable oil production (first of all, palm oil) has started growing in 2015, that is associated, first, with unfavorable climate conditions and natural disasters. However, this growth has been not sufficient to fully satisfy the market and decrease prices. 
Table 4.15

World Rice Import Dynamics Projections by Region

\begin{tabular}{|c|c|c|c|c|c|c|}
\hline \multirow{2}{*}{ Region name } & \multicolumn{5}{|c|}{ Studied and outlook periods, Kt } \\
\cline { 2 - 7 } & $\mathbf{2 0 1 6}$ & $\mathbf{2 0 1 8}$ & $\mathbf{2 0 2 0}$ & $\mathbf{2 0 2 2}$ & $\mathbf{2 0 2 4}$ & $\mathbf{2 0 2 6}$ \\
\hline World & 42293 & 43311 & 45173 & 47018 & 48864 & 50768 \\
\hline Developed countries & 5362 & 5503 & 5609 & 5694 & 5773 & 5862 \\
North America & 1147 & 1190 & 1231 & 1274 & 1316 & 1358 \\
Europe & 1884 & 1892 & 1947 & 1980 & 2011 & 2044 \\
Oceania & 228 & 229 & 230 & 231 & 232 & 232 \\
Other developed countries & 2104 & 2193 & 2200 & 2209 & 2216 & 2228 \\
\hline Developing countries & 36931 & 37808 & 39564 & 41324 & 43090 & 44906 \\
Africa & 13611 & 14543 & 15652 & 16960 & 18382 & 19914 \\
Latin America and Caribbean & 4630 & 4103 & 4129 & 4173 & 4219 & 4249 \\
Asia & 18690 & 19162 & 19783 & 20191 & 20489 & 20743 \\
\hline
\end{tabular}

Source: author's source generalization [6; 12; 52-53]

Table 4.16

World Oilseeds and Oilseed Processing Products Import Dynamics Projections

\begin{tabular}{|c|c|c|c|c|c|c|c|c|}
\hline \multirow{2}{*}{$\begin{array}{c}\text { Food } \\
\text { group } \\
\text { name }\end{array}$} & \multicolumn{5}{|c|}{ Studied and outlook periods, Kt } & \multicolumn{2}{c|}{$\begin{array}{c}\text { Variation 2016 by } \\
\mathbf{2 0 2 6}\end{array}$} \\
\cline { 2 - 9 } & $\mathbf{2 0 1 6}$ & $\mathbf{2 0 1 8}$ & $\mathbf{2 0 2 0}$ & $\mathbf{2 0 2 2}$ & $\mathbf{2 0 2 4}$ & $\mathbf{2 0 2 6}$ & Absolute & $\begin{array}{c}\text { Relative, } \\
\%\end{array}$ \\
\hline $\begin{array}{c}\text { Soybeans } \\
\text { Other } \\
\text { oilseed } \\
\text { crops }\end{array}$ & 144465 & 149155 & 154864 & 162208 & 169347 & 176995 & 32531 & 122.52 \\
\hline \begin{tabular}{c} 
Meal \\
\hline
\end{tabular} & 86872 & 91439 & 94389 & 97148 & 100094 & 103046 & 16174 & 118.62 \\
\hline $\begin{array}{c}\text { Vegetable } \\
\text { oils }\end{array}$ & 77556 & 80175 & 82714 & 85530 & 88576 & 91484 & 13927 & 117.96 \\
\hline
\end{tabular}

Source: author's source generalization [6; 12; 52-53]

Almost half of soybeans produced in the world is sold (Table 4.17). However, Asia will keep being its major consumer. It is projected that soybean import by China will increase by $2.6 \%$ a year up to nearly $117 \mathrm{Mt}$ in 2026 that will make two-thirds of world import. 
World Soybean Import Dynamics Projection by Region

\begin{tabular}{|c|c|c|c|c|c|c|}
\hline \multirow{2}{*}{ Region name } & \multicolumn{5}{|c|}{ Studied and outlook periods, Kt } \\
\cline { 2 - 7 } & $\mathbf{2 0 1 6}$ & $\mathbf{2 0 1 8}$ & $\mathbf{2 0 2 0}$ & $\mathbf{2 0 2 2}$ & $\mathbf{2 0 2 4}$ & $\mathbf{2 0 2 6}$ \\
\hline World & 144465 & 149155 & 154864 & 162208 & 169347 & 176995 \\
\hline Developed countries & 21575 & 21045 & 21287 & 21722 & 21963 & 22474 \\
North America & 930 & 931 & 928 & 933 & 935 & 938 \\
Europe & 16167 & 16184 & 16294 & 16741 & 17001 & 17531 \\
Oceania & 2 & 2 & 2 & 2 & 2 & 2 \\
Other developed countries & 4475 & 3928 & 4063 & 4047 & 4025 & 4004 \\
\hline Developing countries & 122890 & 128110 & 133578 & 140486 & 147384 & 154521 \\
Africa & 2953 & 3515 & 3607 & 3704 & 3818 & 3944 \\
Latin America and Caribbean & 7450 & 7422 & 7508 & 7573 & 7643 & 7728 \\
Asia & 112487 & 117173 & 122463 & 129208 & 135923 & 142849 \\
\hline
\end{tabular}

Source: author's source generalization [6; 12; 52-53]

It is projected that consumption of vegetable oils will grow during the next decade at average rates slower than for the last few years - on average by $1.1 \%$ a year versus $3.1 \%$ (Table 4.18 ). India will remain the largest consumer and importer. It is expected that India will continue to demonstrate growth at the level of $2.6 \%$ per annum and reach an indicator of $21 \mathrm{~kg}$ per capita in 2026.

Table 4.18

World Vegetable Oil Import Dynamics Projections by Region

\begin{tabular}{|c|c|c|c|c|c|c|}
\hline \multirow{2}{*}{ Region name } & \multicolumn{5}{|c|}{ Studied and outlook periods, Kt } \\
\cline { 2 - 7 } & $\mathbf{2 0 1 6}$ & $\mathbf{2 0 1 8}$ & $\mathbf{2 0 2 0}$ & $\mathbf{2 0 2 2}$ & $\mathbf{2 0 2 4}$ & $\mathbf{2 0 2 6}$ \\
\hline World & 77556 & 80175 & 82714 & 85530 & 88576 & 91484 \\
\hline Developed countries & 19201 & 18878 & 18858 & 18930 & 18991 & 18768 \\
North America & 4252 & 4333 & 4399 & 4447 & 4475 & 4490 \\
Europe & 12425 & 11987 & 11852 & 11823 & 11813 & 11515 \\
Oceania & 301 & 300 & 309 & 314 & 319 & 328 \\
Other developed countries & 2223 & 2258 & 2298 & 2345 & 2386 & 2435 \\
\hline Developing countries & 58355 & 61297 & 63857 & 66600 & 69584 & 72716 \\
Africa & 9748 & 10206 & 10846 & 11417 & 12111 & 12861 \\
Latin America and Caribbean & 4824 & 4885 & 4892 & 4886 & 4890 & 4905 \\
Asia & 43783 & 46205 & 48119 & 50297 & 52584 & 54951 \\
\hline
\end{tabular}

Source: author's source generalization [6; 12; 52-53] 
The largest oilseed meal importer is the EU, where import will continue to slowly increase - approximately, by $0.3 \%$ a year (Table 3.19 ). Further, it is expected that import will grow in Asia, especially, Vietnam and Philippines will increase their import by $3.0 \mathrm{Mt}$ and $0.8 \mathrm{Mt}$ by 2026 , respectively.

Table 4.19

World Oilseed Meal Import Dynamics Projections by Region

\begin{tabular}{|c|c|c|c|c|c|c|}
\hline \multirow{2}{*}{ Region name } & \multicolumn{6}{|c|}{ Studied and outlook periods, Kt } \\
\cline { 2 - 7 } & $\mathbf{2 0 1 6}$ & $\mathbf{2 0 1 8}$ & $\mathbf{2 0 2 0}$ & $\mathbf{2 0 2 2}$ & $\mathbf{2 0 2 4}$ & $\mathbf{2 0 2 6}$ \\
\hline World & 86872 & 91439 & 94389 & 97148 & 100094 & 103046 \\
\hline Developed countries & 39179 & 41263 & 41802 & 42130 & 42695 & 43193 \\
North America & 4678 & 4977 & 5054 & 5085 & 5214 & 5424 \\
Europe & 27908 & 29363 & 29629 & 29848 & 30115 & 30134 \\
Oceania & 2942 & 3227 & 3409 & 3550 & 3692 & 3830 \\
Other developed countries & 3651 & 3695 & 3709 & 3647 & 3674 & 3806 \\
\hline Developing countries & 47693 & 50176 & 52587 & 55018 & 57399 & 59852 \\
Africa & 5405 & 5508 & 5868 & 6260 & 6666 & 7095 \\
Latin America and Caribbean & 10226 & 10978 & 11374 & 11763 & 12066 & 12404 \\
Asia & 32062 & 33690 & 35345 & 36994 & 38667 & 40354 \\
\hline
\end{tabular}

Source: author's source generalization [6; 12; 52-53]

\section{Regional features of FAO support and partnership in achieving sustainable development of agriculture and rural areas}

A regional approach is a current trend for the UN now and it tries to follow it in its work. It is worth saying that such approach is an actually efficient basis for strategic planning as well as for space, food system and rural location management. It is important to note that the necessity to engage regional organizations and such approach to pursuing policy is not something new for the UN. This was let be known back in 1995 within the framework of the Joint Inspection Unit at the UN General Assembly [3].

Regionalism largely determines not only the UN action methods but also influences its reforming. The importance of existing approach and its recognition are actually confirmed by the fact that the UN recognizes it and notes the need to follow it. It promotes improvement of productivity of global processes, which continues to remain the UN task. Moreover, it is expected to expand exactly regional and sub-regional activities, rebuild the development system and take measures for its reorientation subject to a 
regional approach that is confirmed by the UN General Assembly Resolution of 31 May 2018.

The FAO also abides by a regional orientation in it activities. Within the framework of its activity, it is emphasized, that important are not only global efforts but also decentralization, clear separation of duties and introduction of existing experience locally, takin into account regional specifics both at the level of the region itself and for coordination of country programs; FAO sub- and regional offices actively interact on a bilateral basis. Reasons for such FAO approach should be highlighted [30; 44]:

1) many threats to ensuring food safety, especially, caused by natural and climate change, are not able to account for existing state borders (for example, it concerns the aquatic ecosystems);

2 ) work on improving the ecosystems often envisages joint actions of several nearby states;

3) linking of production processes in agriculture as well as economic interdependence and involvement in the world food market (for example, a serious crisis in one country is able to affect neighboring countries);

4) political and military conflicts often take place not within the borders of one country, but come up to a regional level that can result in significant effects for the region in general.

Further, in the context of the FAO regional policies, a regional division used by the FAO should be mentioned:

1) there are regional offices of the FAO for: Africa; Asia and the Pacific; Europe and Central Asia; Latin America and the Caribbean; the Near East;

2) subregional offices of the FAO for: Central Africa; the Mashreq countries, Lebanon, Beirut; Central America; Central Asia; East Africa; North Africa; Southern Africa; the Caribbean; the Gulf Cooperation Council States and Yemen; the Pacific Islands;

\section{Country offices.}

Improvement and use of preventive support and partnership methods may be called as the main feature of the UN approach to holding negotiations and building relations. It is known that the idea of preventivism belonged to the UN Secretary-General Dag Hammarskjold and was proclaimed back in 1971 in the 25th session of the UN General Assembly. "In terms of preventive actions, the UN continuously keeps track of possible sources of tension inside and among the states in order to contain and regulate possible 
conflicts. Priority is given here to their root causes. Essential elements of preventive support and partnership are establishment of facts, respective analysis, early warning and political will to prevent conflict transformation into an outbreak of violence. At the same time, the UN proceeds from the premise that preventive support and partnership should be outwardly lowkey and restrained by virtue of risk of unintentional escalation caused by drawing of international attention to a potential conflict" [11]. So prevention of conflicts using "quiet diplomacy" is one of the key features of providing preventive support and partnership by the UN in general, especially, after the end of the Cold War. Another feature is a capability of holding negotiations with various structures - with both official representatives of the states and representatives on non-governmental organizations. And, if it comes to diplomacy of organizations of the "UN family", then it is possible here to hold negotiations at the level of the population ("grass-roots" level), for example, assistance in resolution of conflicts between peasants in African rural communities.

FAO support and partnership is implemented, mainly, by holding numerous conferences, summits, meetings to solve the food problem tasks. One of the priorities of the FAO negotiation activities is reaching compromise. Presumably, behind-the-scenes meetings between organization member states on a bilateral basis, just like on a multilateral basis, anyway, are held though negotiations, in the course of which the parties strive to find solutions satisfying all participants in the negotiation process. In order to do that, a free information exchange is provided, and aspiration to understand a negotiation partner is definitely on hand. So, negotiators' attention is focused on the uniting moments rather than differences, and thus, a probability to make a decision by consensus enhances.

In 1974, as a platform for coordination of FAO member activities and consulting on food problematics, the Committee on World Food Security was established. In 2009, on the wave of the food crisis, the Committee was reformed, the representatives of the civil society and NGOs have come into it as well as into other specialized UN institutions. Reforms involve aligning the UN policy, combining joint efforts of members at all levels, including a local level. Such measures will also allow to make more efficient decisions based on a multilateral and in-depth analysis with respect to all distressed regions [31]. 
Considering the FAO policy "at grass-roots levels", note that, of the latest programs, a program of cooperation with more than $36 \mathrm{~K}$ farmers in Lesotho can be highlighted. It is carried out jointly with the EU and Ministry of Agriculture and Food Security. The purpose of the program is to use own levers of influence and establish contacts between the farmers in order to end strikes and prevent food crisis escalation. In connection with an increase in prices for food, the economy of Lesotho has significantly suffered that resulted in strikes and dismissals. In the meantime, agriculture, on which successful functioning $1.9 \mathrm{M}$ people depends, is the major industry of the country. So, successful negotiations with the farmers and ending strikes are able to assist in solving a food problem and prevent an oncoming crisis in Lesotho. Carrying out and arranging negotiations at the "grassroots" level also constitutes an integral part of the FAO policy. This is necessary as a result of the need to regularly solve local conflicts preventing their transition to a more serious phase. Over the past decade, the number of conflicts has significantly increased and they have become more complicated and hard-to-solve, while $60 \%$ of all undernourished people reside just in the conflict zones. The impact of the conflict on food security can be both direct (this is destruction of farmer household and food stocks) and indirect (for example, malfunctioning of food supply and food market systems that reflects on price formation).

As was noted by the former FAO Director-General, "it is the conflicts that continue to be a major threat to food security in 18 countries, the majority of which are in Africa and in the Near East. Climate distresses, in particular, drought, are the major cause of food crises in 23 countries, mainly, African countries, on which territory almost $40 \mathrm{M}$ people live under acute food shortage conditions" [43]. It is remarkable that food security matters, ensuring development in the agricultural sector and conflicts have an inverse dependence. Solution to these problems helps eliminate important reasons for conflicts and serve as a linchpin of peace and aspiration for common interaction.

More than half of the planet population, many of whom live in rural areas, have no way to provide themselves an adequate social protection level. This has become one of the reasons, due to which the FAO has started making notable attempts to help the states in this area as well as recommend them to consider the social protection matters as a component part 
of national security of the state and as an important aspect of development strategies. The important point in the social protection programs is that even large programs do not become a burden for a state budget. In this respect, the most striking is an example of developing countries with a high poverty level. Implementing social protection of the population within the framework of the FAO programs leads to the following results impacting food security $[42 ; 65]$ :

1) increasing in citizen incomes and decreasing in a poverty threshold not only by direct financing but also by improving access to public services as well as supporting those who are in an unfavorable position in the labor market;

2) social protection programs often promote more qualitative distribution of food resources on a direct basis;

3) particular cases when financial aid within the framework of social protection had an impact, inter alia, on increasing in investments in agricultural activities though the increased social capital;

4) an opportunity to free children from labor, which is often needed to shorten the family budget deficit. It makes an impact on human capital that also positively effects food security;

5) slowing the spread of human immunodeficiency virus and acquired immunodeficiency syndrome. This promotes both filling an agricultural market with labor force and more correct distribution of resources at all levels - from acquisition of medications and rendering of medical aid for food acquisition and to investments in agriculture;

6) improving access for the population to agricultural resources and new technologies, upgrading qualification of specialists employed in the industry.

FAO support and partnership exemplifies an opportunity for making significant changes and solving major problems without considerable financial infusions.

One of the FAO roles is a mediation role within the framework of enhancing and establishing the relationships in multilateral negotiations between the states and NGOs, strengthening, thus, food security. This is the FAO that makes every effort to provide coming of required investments in agriculture, fishery and forestry as well as of expenses for study and building of development models. It is required for establishing new sustainable production systems applying new technological rational and saving 
methods. In its turn, this will enable farmers, ecosystems and people to adapt themselves and mitigate the effects of climate change and meet both specific needs of one or another country and global tasks.

The EU role in the implementation of FAO programs should be specially noted. A specific character of this relationship is confirmed by the agreement signed between them in 2003 for achieving a common goal - rising in level standards in developing countries, providing humanitarian aid to them [24]. At present, this cooperation continues to be a priority area of FAO activities. Upon signing the agreement, the EU was directly involved in many projects financially as well, having allocated $1.5 \mathrm{~B}$ euros for joint project implementation. The FAO recognizes that "this cooperation is successful and fruitful as well as that it is an important tool for improving life of the humanity in the whole world" [58]. One should note the justice of the recognition of this cooperation as the key to the FAO work as, actually, there are studies confirming the EU's impact on world food security, the EU is an acknowledged global leader in rendering donor aid to the FAO and other UN units. The European Union achieves this not only through food supplies onto the market, but also by focusing on developing the agricultural sector in general as well as by eliminating own policy shortcomings, which were making an adverse impact on the world food market.

UN uniqueness and alternative lessness in the world arena provides a special status for the FAO. Conference activity, communication at several levels at once and simultaneous interaction with various stakeholders as well as performance of a role of a negotiation planform and comprehensiveness of approach to problem solution are major features of FAO support and partnership. FAO "food diplomacy" is an important element in solving complex food problems in developing countries. FAO democratic principles in negotiation processes, use of support and partnership methods, "grass-roots" negotiations create the necessary prerequisites for reaching decisions by consensus in food security matters, achieving goals of sustainable developments of agriculture and rural areas.

\section{Conclusions}

The undertaken study allowed to achieve the main goal of this work - to identify the most promising mechanisms of the UN and the "UN Family", in particular FAO, interaction with national state institutions for the sustain- 
able development of the agricultural sector of the economy based on the theoretical and methodological approaches enhancing and the best world practices adaptation for the SDGs implementation to the correspondent state regulators and agricultural commodity producers, taking into account the prediction of tactical and tectonic shifts in world food consumption volume and in the context of the key administrative groups and locations (regions). To achieve this goal, the set tasks were consistently solved in the process of the undertaken study, what allowed to offer the following conclusions and concepts:

firstly, the dominance of the ecological-centric approach to the sustainable development (originated during the latter half of the twentieth century in the context of the environmental issues popularization on the global agenda) not only gave rise to the methodological concepts of "environmental economy", "strong sustainability", "ecological modernization", anthroposphere narrative, but also logically inert them firstly in the MDGs (2000-2015), and eventually to the SDGs (2016-2030), that contain the basic ideas of this approach - climate action and environmental protection, which are still relevant in the global agenda. In this regard, the equivalency and interdependence of the "economic growth - social well-being - environmental sustainability" triad run like a golden thread through the SDGs, which by the means of fundamental link between people and the planet involve the economic agricultural sector into the sustainable food production and rural areas development. For these reasons, in the SDGs there was formulated a comprehensive concept of "End hunger, achieve food security and improved nutrition and promote sustainable agriculture", which stimulates the achievement of all UN program goals for the period by 2030, primarily: the poverty eradication (goal № 1), unimpaired health (goal № 3), gender equality (goal № 5), pure water (goal № 6), economic growth (goal № 8), industrialization, innovation and infrastructure (goal № 9), inequality reduction (goal № 10), responsible consumption and production (goal № 12), climate action (goal № 13), oceans and seas (goal 14), ecosystems, biodiversity and forests (goal № 15) and peaceful societies (goal № 16);

secondly, the sustainable development of the agricultural sector of the economy, along with the food problem, is questionable and multidimensional as it brings social, economic and political demand, and impacts on all aspects of society, that is why its solution is the base for not only "poor" 
countries survival, but also for the whole world community. The rapid population growth, including the global food resource base depletion, questions the international community about the effective measures developing to overcome the crisis. In this regard, it can be said that the FAO foundation has become a rather effective institutional option for solving the problem of sustainable development of the economic agricultural sector. The symbiosis of economic, social and political mechanisms has allowed not only to stop world hunger-bitten people growth, but also to formulate the ambitious goal of "Zero Hunger" and coordinate (facilitate) its implementation taking into account the Quattro-factor "production - distribution - exchange - food consumption" in global regions and in particular countries, and also the resistance of stakeholders' system forming: FAO substructures (Investment center GDP et al.); specialized organizations of the "UN Family" (IFAD, UNICEF, WHO et al.); donor countries (EU, USA, etc.); non-state actors (INGOs, TNC, charity funds, etc.);

thirdly, the dualism of regionalism, along with the solution of the UN and "UN Family", in particular the FAO, global food problem significantly determines not only the methods of the organization's influence on the regional (local) policy of sustainable economic agricultural sector development, but also forms the corresponding shifts in the administrative and assortment food consumption line by particular countries, regions and the world at large. It made possible to reappraise the "Agricultural Outlook" prepared by the consolidated efforts of the OECD and FAO for the period 2017-2026 from the perspective of the SDGs and FAO policy impact on the invariance of the food market changes and changes in the group of key food consumers' (importers') countries. At the same time, the base period of 2016 was not taken by chance, it allows to use the base period as a "zero" reference point of countrywise implementation in the economic agricultural sector activity, the relevant objectives of the SDGs, tracing their change till 2026, from the perspective of statics and a low level of the countries' restructuring dynamics - food donors and importers. In this regard, the obtained predictions of Brazil food production growth record at the level of $40 \%$ and $20 \%$ of food growth in China, India, the Russian Federation and Ukraine will make it possible to achieve the corresponding SDG targets for the period up to 2030 if in the short-term prospects they will manage to solve the problem of the coronavirus world spread, and in the medium term 
prospects - to provide the negotiation of global manufacture recession and overcoming the growth of trade barriers in the world economy;

fourthly, the dividing of FAO regional program activity in the framework of support and partnership to achieve sustainable economic agricultural sector development into three groups (1) depending on the regions of application; 2) a target group of countries in need; 3 ) on targets (for example, "Zero Hunger") allowed to reveal the features of "FAO-diplomacy" (synergy of "quiet diplomacy" and negotiations at the "grass-roots" level), which is a key tool for the agricultural production systems stimulation and specific locations (first of all in developing countries) as SDGs achievement, taking into account possible risks (civil wars and ethnic conflicts), as well as growth of uncertainty and institutional contradictions in the development of state regulatory institutions in developing countries in general and particularly in Ukraine.

The main concepts of this investigation can be subsequently developed by both globalist and niche economists, in other words agro-economists, on the issues related to the international organizations activity in ensuring the sustainable development of the agricultural sector of the economy and solving the global food problem in the context of a new format search for the development of Ukrainian agriculture and rural areas, its transition to the stability-driven development.

\section{References:}

1. Hungry world. Ukraine is one of the leaders of Global Hunger Index-2017. (2017, October 19). LIGhA.net. Retrieved from: https://www.liga.net/economics/ infografica/global-hunger-index-2017-ukraintsy-budut-syty (in Ukrainian)

2. State Statistics Committee of Ukraine (n.d.). Retrieved from: http://www.ukrstat.gov.ua (in Ukrainian)

3. General Assembly United Nations (1995, October 17). Peacekeeping Responsibility Report: $U N$ and Regional Organizations. Retrieved from: https://www.unjiu.org/sites/www.unjiu.org/files/jiu_rep_1995_4_russian.pdf (in Russian)

4. DEIF. (n.d.) The share of expenditure on food (food) in the world. Retrieved from: https://deepcool-ma.com/dolya-rasxodov-na-pitanie-edu-v-stranax-mira/.html (in Russian)

5. Ministry of Agrarian Policy and Food of Ukraine (2015, October 26). Single and Comprehensive Strategy and Action Plan for Agriculture and Rural Development in Ukraine for 2015-2020 (Draft). Retrieved from: http://extwprlegs1.fao.org/docs/ pdf/ukr169405.pdf.

6. Zablovskyj A.V., Petrukha S.V., Petrukha N.N. (2017). Sel'skoe khozyaystvo $v$ sisteme ustoychivogo razvitiya mirovoy ekonomiki [Agriculture in the system of 
sustainable development of the world economy]. Rozvytok ekonomiky Ukrajiny: transformaciji ta innovaciji [Economic Development of Ukraine: Transformation and Innovation]. Zaporizhzhia: Helvetica Publishing House, pp. 49-67. (in Russian)

7. State Statistics Committee of Ukraine (2019). Employed population by type of economic activity in 2012-2018. Retrieved from: http://www.ukrstat.gov.ua/ operativ/operativ2014/rp/zn_ed/zn_ed_u/zn_ed_2013_u.htm (in Ukrainian)

8. Ivannikov N.S. (2019). Régional'nye osobennosti politiki OON v sfere prodovol'stvennoy bezopasnosti [Regional features of UN food security policy] (PhD Thesis). St. Petersburg: Peter the Great St. Petersburg Polytechnic University. (in Russian)

9. Lupashko-Stal'skiy I.P. (2006). Prodovol'stvennaya i sel'skokhozyaystvennaya organizatsiya Ob"edinennykh Natsiy (FAO) [Food and Agriculture Organization of the United Nations]. Moscow: Rosinformagroteh. (in Russian)

10. Maksakovskiy V.P. (2002). Global'naya prodovol'stvennaya problema i ee geograficheskie aspekty [Global food problem and its geographical aspects]. Geography (electronic journal), no. 19. Retrieved from: https://geo.1sept.ru/article. php?ID=200201908 (accessed 26 February 2020). (in Russian)

11. United Nations (2017). Review of mechanisms and policies addressing conflict of interest in the United Nations system. Retrieved from: https://www.unjiu.org/ sites/www.unjiu.org/files/jiu_rep_2017_9_russian.pdf (in Russian)

12. Petrukha S.V. (2018). Derzhavne antykryzove reghuljuvannja aghrarnogho sektoru ekonomiky Ukrajiny [State Anti-crisis Regulation of the Ukrainian Economy Agrarian Sector]. Kyiv: Center for Educational Literature. (in Ukrainian)

13. Petrukha S.V. (2017). Porivnjaljnyj analiz reghuljuvannja aghrarnogho sektoru v umovakh zaghostrennja konkurenciji na svitovykh prodovoljchykh rynkakh [The Comparative Study of Agrarian Sector Regulation Under the Conditions of Escalating Competition on the World Food Markets]. Efektyvna ekonomika (electronic journal), no. 11. Retrieved from: http://www.economy.nayka.com.ua/ ?op $=1 \& z=5880$ (in Ukrainian)

14. Petrukha S.V. (2017). Rynkova transformacija aghrarnogho sektoru ekonomiky Ukrajiny: vid aghrarnoji kryzy do formuvannja pidvalyn realizaciji Ghlobaljnykh Cilej Stalogho Rozvytku [Market Transformation of Agricultural Sector of Ukraine's Economy: from Agricultural Crisis to Formation the Basis for Achievement the Global Sustainable Development Goals]. Agrosvit, no. 18, pp. 3-46. (in Ukrainian)

15. Cabinet of Ministers of Ukraine (2016). Approving the Poverty Reduction Strategy (Order, No. 161-p, March 16). Retrieved from: https://www.kmu.gov.ua/ npas/248898080 (in Ukrainian)

16. Cabinet of Ministers of Ukraine (2013). On approval of the Strategy for the development of the agricultural sector for the period up to 2020 (Order, No. 806-p, October 17). Retrieved from: http://zakon2.rada.gov.ua/laws/show/ 806-2013-\%D1\%80 (in Ukrainian)

17. Cabinet of Ministers of Ukraine (2019). Approval of the Strategy for Promoting Private Investment in Agriculture for the Period up to 2023 (Order, No. 595-p, July 5). Retrieved from: https://zakon.rada.gov.ua/laws/show/595-2019-\%D1\%80 (in Ukrainian) 
18. Presidential Office (2019). On the Sustainable Development Goals of Ukraine until 2030 (Presidential decree, No. 722/2019, September 30). Retrieved from: https://www.president.gov.ua/documents/7222019-29825 (in Ukrainian)

19. Sabluk P.T., Bilorus O.Gh., Vlasov V.I. (2008). Ghlobalizacija i prodovoljstvo [Globalization and food]. Kiev: Publishing House National Science Center "Institute of Agrarian Economy". (in Ukrainian)

20. Libanovoji E.M., Khvesyka M.A. (ed.) (2017). Socialjno-ekonomichnyj potencial stalogho rozvytku Ukrajiny ta jiji reghioniv: vektory realjnogho postupu [Socioeconomic potential of stalogho rozvytku Ukrainy ta jiji reghioniv: vektory realjnogho postupu], Kyiv: Public Institution "Institute of Environmental Economics and Sustainable Development of the National Academy of Sciences of Ukraine". (in Ukrainian)

21. Lupenko Ju.O. (ed.) (2019). Proceedings of the Strateghija rozvytku siljsjkogho ghospodarstva ta siljsjkykh terytorij (Ukraine, Kyiv, October 10, 2019), Kyiv: Publishing House National Science Center "Institute of Agrarian Economy", 202 p. (in Ukrainian)

22. Ukrainian Institute of Politics. (n.d.) Ukrainians spend more than half of their income on food. Retrieved from: https://uiamp.org.ua/ukraincy-tratyat-bolee-poloviny-dohodov-na-produkty-pitaniya (in Ukrainian)

23. UN News (2017). FAO, World Bank Sign Hunger and Poverty Agreement. Retrieved from: https://news.un.org/ru/story/2017/05/1304571 (in Ukrainian)

24. UN News (2003). FAO, EU strengthen hunger partnership. Retrieved from: https://news.un.org/ru/story/2003/07/1040671 (in Ukrainian)

25. The United Nations in Ukraine (2015). Millennium Development Goals. Ukraine: 2000-2015. 124 p. (in Ukrainian)

26. Ministry of Economic Development and Trade (Ukraine) (2017). Sustainable Development Goals. Ukraine: 2016-2030. 176 p. (in Ukrainian)

27. "Land" bill: Parliament considered 1193 changes from 4018. (2020, February 20). Ukrainian Pravda. Retrieved from: https://www.epravda.com.ua/rus/ news/2020/02/20/657305 (in Ukrainian)

28. United Nations. (n.d.) About the United Nations. Retrieved from: https://www.un.org/en/about-un/index.html

29. Food and Agriculture Organization of the United Nations. (n.d.) Achieving Zero Hunger by 2030 requires turning political will into concrete actions. Retrieved from: http://www.fao.org/news/story/en/item/902483/icode

30. Bafoil F. (2013). Resilient States from a Comparative Regional Perspective (Central and Eastern Europe and Southeast Asia). World Scientific Publishing Company.

31. Food and Agriculture Organization of the United Nations. (n.d.) Communication Strategies for Rural Development. Retrieved from: http://www.fao.org/ 3/u1320e/u1320e 01.htm

32. World Summit on Food Security (2009). Declaration Of The World Summit On Food Security. Retrieved from: http://www.fao.org/tempref/docrep/fao/ Meeting/018/k6050e.pdf

33. The Integrated Food Security Phase Classification. (n.d.) Desert locusts could worsen food insecurity in East and Horn of Africa. Retrieved from: http://www.ipcinfo.org/ipcinfo-website/ipc-alerts/issue-18/en 
34. IFAD. (2010) Enabling poor rural people to improve their food security, raise their incomes and strengthen their resilience. Retrieved from: https://webapps.ifad.org/members/eb/101/docs/EB-2010-101-R-12.pdf

35. Food and Agriculture Organization of the United Nations. (n.d.) FAO appeals for urgent support to fight worsening Desert Locust upsurge in the Horn of Africa. Retrieved from: http://www.fao.org/news/story/en/item/1259082/icode

36. Food and Agriculture Organization of the United Nations (2008). FAO's Initiative on Soaring Food Prices Guide for immediate country level action. Retrieved from: http://www.fao.org/fileadmin/templates/worldfood/Reports_and_ docs/IFSP_guide_immediate_action.pdf

37. Food and Agriculture Organization of the United Nations. (n.d.) Feeding people and protecting our planet should go hand in hand. Retrieved from: http://www.fao.org/news/story/en/item/1237532/icode

38. World Food Programme. (n.d.) Food Assistance for Assets. Retrieved from: https://www.wfp.org/food-assistance-for-assets?_ga=2.251931594.2123761392. 1582800714-1829558488.1581932520

39. International Food Policy Research Institute. (n.d.) Global Hunger Index. Retrieved from: http://www.foodsecurityportal.org/countries

40. Food Security Information Network (2019). Global Report on Food Crises (Regional Focus on the Intergovernmental Authority on Development Member States). 2019. Retrieved from: http://fsinplatform.org/sites/default/files/resources/ files/IGAD \%202019\%20online.pdf

41. World Health Organization (2018). Healthy diet. Retrieved from: https://www.who.int/ru/news-room/fact-sheets/detail/healthy-diet

42. Food and Agriculture Organization of the United Nations. (n.d.) Homestead gardening brings hope as Lesotho seeks to adapt to climate change. Retrieved from: http://www.fao.org/news/story/en/item/340250/icode

43. Food and Agriculture Organization of the United Nations. (n.d.) Increasing food production without damaging the environment. Retrieved from: http://www.fao.org/news/story/en/item/889671/icode

44. Food and Agriculture Organization of the United Nations. (n.d.) Increasing resilience at the regional level. Retrieved from: http://www.fao.org/resilience/ regional-approach/en

45. The Office of the High Commissioner for Human Rights. (n.d.) International Covenant on Economic, Social and Cultural Rights. Retrieved from: https:/www.ohchr.org/en/professionalinterest/pages/cescr.aspx

46. Food and Agriculture Organization of the United Nations. (n.d.) Investment Centre. Retrieved from: http://www.fao.org/investment-centre/en

47. The Integrated Food Security Phase Classification. (n.d.) IPC overview and classification system. Retrieved from: http://www.ipcinfo.org/ipcinfo-website/ ipc-overview-and-classification-system/en

48. FAO/WFP (2009). Joint Guidelines for Crop and Food Security Assessment Missions. Retrieved from: http://www.fao.org/3/i0515e/i0515e.pdf

49. Keynes J.M. (1963). Economic Possibilities for our Grandchildren. Persuasion. N.Y.: W. W. Norton \& Co. 


\section{Chapter «Economic sciences»}

50. Food and Agriculture Organization of the United Nations. (n.d.) Monitoring food security in countries with conflict situations. Retrieved from: http://www.fao.org/3/ ca5938en/CA5938EN.pdf

51. World Health Organization (2018). Obesity and overweight. Retrieved from: https://www.who.int/news-room/fact-sheets/detail/obesity-and-overweight

52. OECD/FAO. (2012). OECD-FAO Agricultural Outlook 2012-2021. Retrieved from: http://www.fao.org/fileadmin/templates/est/COMM_MARKETS MONITORING/Oilcrops/Documents/OECD Reports/Ch5StatAnnex.pdf

53. OECD/FAO. (2017). OECD-FAO Agricultural Outlook 2017-2026. Retrieved from: http://www.fao.org/3/a-i7465e.pdf

54. Petrukha S. (2017). The economic mechanism of the crisis management in the agrarian sector of economy of Ukraine. Formation of modern social, economic and organizational mechanisms of entities agrarian business. Riga: ISMA University, pp. 35-42.

55. Food and Agriculture Organization of the United Nations (2015). Plan of Action (2015-2019): Resilient Livelihoods for Sustainable Agriculture, Food Security and Nutrition. Retrieved from: http://www.fao.org/fileadmin/user upload/ FAO-countries/Sudan/docs/SudanCPF-PoA/SudanCPF-PoA.pdf

56. Food and Agriculture Organization of the United Nations. (n.d.) Policy Support and Governance. Retrieved from: http://www.fao.org/policy-support/governance/ru

57. Regional Organization for the Protection of the Marine Environment. (n.d.). Retrieved from: http://ropme.org/home.clx

58. Landell Mills International (2018). Study on highlights of FAO-EU cooperation 2007-2017. Retrieved from: https://eeas.europa.eu/sites/eeas/files/study_on eu-fao_cooperation_2007-2017_final_report.pdf

59. The Integrated Food Security Phase Classification (2019). Technical Manual Version 3.0 (Evidence and Standards for Better Food Security and Nutrition Decisions). Retrieved from: http://www.ipcinfo.org/fileadmin/user_upload/ipcinfo/ manual/IPC_Technical_Manual_3_Final.pdf

60. Food and Agriculture Organization of the United Nations \& United Nations World Food Programme (2009). The State of Food Insecurity in the World (Economic crises - impacts and lessons learned). 2009. Retrieved from: http://www.fao.org/3/i0876e/i0876e.pdf

61. Food and Agriculture Organization of the United Nations; International Fund for Agricultural Development \& United Nations World Food Programme (2014). The State of Food Insecurity in the World. 2014. Retrieved from: http://www.fao.org/3/a-i4030e.pdf

62. Food and Agriculture Organization of the United Nations (2019). The State of Food Security and Nutrition in the World 2019. Retrieved from: http://www.fao.org/3/ ca5162en/ca5162en.pdf

63. Food and Agriculture Organization of the United Nations; International Fund for Agricultural Development; UNICEF; World Helth Organization \& United Nations World Food Programme (2017). The State of Food Security and Nutrition in the World. 2017. Retrieved from: http://www.fao.org/3/a-i7695e.pdf 
64. General Assembly United Nations (2015). Transforming our world: the 2030 Agenda for Sustainable Development. Retrieved from: https://www.ua.undp.org/ content/ukraine/uk/home/library/sustainable-development-report/the-2030-agenda-for-sustainable-development.html

65. Food and Agriculture Organization of the United Nations. (n.d.) Why social protection holds the key to fighting hunger. Retrieved from: http://www.fao.org/zhc/ detail-events/en/c/296547

66. International Monetary Fund (2019). World economic outlook. Global Manufacturing Downturn. 208 p. 